\title{
Effect of feeding according to energy balance on performance, nutrient excretion, and feeding behavior of early lactation dairy cows
}

\author{
E. Maltz, ${ }^{*} \dagger$ L. F. Barbosa, ${ }^{*}$ P. Bueno, ${ }^{*}$ L. Scagion, ${ }^{*}$ K. Kaniyamattam, ${ }^{*}$ L. F. Greco, ${ }^{*}$ A. De Vries, ${ }^{*}$ \\ and J. E. P. Santos*1 \\ *Department of Animal Sciences, University of Florida, Gainesville 32611 \\ †Institute of Agricultural Engineering, Agricultural Research Organization, The Volcani Center, Bet Dagan, Israel 50250
}

\section{ABSTRACT}

The objectives of this study were to evaluate 2 feeding strategies for early lactation cows on performance and efficiency of nutrient utilization. Fifty-eight Holsteins cows were blocked by parity and production during the pretreatment period and then randomly assigned at $21 \mathrm{~d}$ postpartum to a control diet $[\mathrm{n}=29 ; 16.2 \%$ crude protein, $1.64 \mathrm{Mcal}$ of net energy for lactation $\left(\mathrm{NE}_{\mathrm{L}}\right), 22 \%$ starch, and $19 \%$ forage neutral detergent fiber (NDF)] or a diet with caloric density manipulated weekly (precision diet; $\mathrm{n}=29 ; 16.2 \%$ crude protein; 1.59 to $1.68 \mathrm{NE}_{\mathrm{L}} ; 18$ to $26 \%$ starch; and 16 to $22 \%$ forage NDF) to promote a calculated positive energy balance of $5 \mathrm{Mcal} /$ day. Diets were fed as total mixed rations and precision cows had their diets adjusted individually once a week, by feeding additional grain supplementation from 0 to $25 \%$ of daily dry matter (DM) offered, according to the energy balance of the preceding week. Energy balance was calculated daily and then averaged weekly. The study lasted from wk 3 to 19 postpartum, and nutrient digestibility, rumen fluid composition, urinary output, estimates of microbial protein synthesis, and feeding behavior were evaluated between wk 9 and 13 postpartum. Compared with controls, precision cows had similar DM intake $(24.3 \mathrm{~kg} / \mathrm{d})$, but $\mathrm{NE}_{\mathrm{L}}$ intake tended to be greater primarily between wk 4 and 8 postpartum. Yields of milk (45.2 vs. $41.9 \mathrm{~kg} / \mathrm{d}$ ), milk components, $3.5 \%$ fat-corrected milk (44.0 vs. 40.8 $\mathrm{kg} / \mathrm{d}$ ), and energy-corrected milk (43.4 vs. 40.2 ) were all greater for precision than control cows, resulting in greater energy-corrected milk production per kilogram of diet DM consumed (1.79 vs. 1.72). Precision cows produced more milk calories per kilogram of metabolic weight ( 0.227 vs. $0.213 \mathrm{Mcal}$ of $\mathrm{NE}_{\mathrm{L}} / \mathrm{kg}$ ), although the amount of consumed calories partitioned into milk $(82.3 \%)$ and measures of energy status did not differ between treatments throughout the study. Glucose concentrations were greater throughout the day in pre-

Received January 4, 2013.

Accepted April 14, 2013.

${ }^{1}$ Corresponding author: jepsantos@ufl.edu cision cows compared with controls at 6 wk, but not 13 wk postpartum. Apparent digestibility of nutrients, composition of rumen fluid, mean and low rumen $\mathrm{pH}$, and estimated rumen microbial $\mathrm{N}$ synthesis remained mostly unaltered by treatments. Although precision cows produced more milk true protein, measures of efficiency of dietary $\mathrm{N}$ use were not influenced by treatment. On wk 13 postpartum, precision cows consumed a diet with longer NDF particles, which resulted in a tendency for greater intake of NDF $>8 \mathrm{~mm}$ because of less sorting against the long particles than control cows. Meal pattern differed with treatment, and precision cows consumed feed more sparsely throughout the day, spent more time ruminating lying, and had similar meal duration (mean of $36.3 \mathrm{~min} / \mathrm{meal}$ ) compared with control cows, but smaller meal size (3.33 vs. $3.64 \mathrm{~kg} /$ meal). Results from the current study indicate that allocating dietary resources according to the individual needs of cows based on energy balance improves lactation performance compared with feeding a single total mixed ration, despite similar average nutrient intake between treatments. Improvements in performance are likely related to allocation of calories based on the needs of the cow and on shifts of feeding behavior that might favor intake of smaller meals.

Key words: dairy cow, energy balance, nutrient utilization, precision feeding

\section{INTRODUCTION}

The goal of any feeding program is to provide the correct and balanced amount of nutrients to a cow at the proper time to achieve optimum production, reproductive efficiency, and profitability. Applying these guidelines to every single cow in the herd would create the optimal results, provided the correct amount and balance of nutrients to cows at the proper time are known. Guidelines for nutrient requirements of dairy cows have been well established in different countries utilizing different methodologies, one of them being the NRC in North America (NRC, 2001). Nevertheless, technological and practical limitations, as well as expansion of herd size, have diverted management from 
the individual to the group-feeding approach. No single system is correct for all dairy producers; however, the emerging feeding method of choice for both small and large dairy herds is a TMR (NAHMS, 2002). The guidelines for TMR feeding is to formulate a diet to address a theoretical representative cow that may be the average or in the upper percentile in the herd or the group. Under these circumstances, feeding a TMR according to a theoretical average cow will potentially underfeed or overfeed a large proportion of the herd, especially when the entire lactating herd receives a single ration throughout lactation. The assumption that higher-producing cows will compensate by consuming more DM and lower-producing cows by consuming less DM might not always happen, therefore, creating a wide range of BCS at dry-off and at calving, particularly when lactation is extended by delayed pregnancy. Overfeeding less productive cows will likely increase excretion of $\mathrm{N}$ and other nutrients, and increasing the forage content of the TMR of high-producing cows reduces efficiency of dietary N utilization (Aguerre et al., 2011).

Studies have evaluated alternatives to a single TMR by establishing feeding groups of cows with similar characteristics, primarily stage of lactation and lactation potential (Spahr et al., 1993), and adjusting the caloric density and composition of the ration accordingly. This is particularly important in early lactation, when nutrient secretion in milk is not compensated for by a rapid increase in DMI. Because of that, cows undergo a period of negative nutrient balance and extensive body tissue mobilization (Coffey et al., 2002). Attempts to adjust concentrate supplementation according to milk production has had mixed success, even under controlled conditions, because milk yield itself does not provide sufficient information for accurate application of a more precise feeding program (Maltz et al., 1992). The availability of daily BW measurements improved the accuracy of concentrate supplementation (Maltz et al., 1992; Maltz, 1997; Maltz et al., 1997), and attempts to apply individual supplementation with computer-controlled self-feeders according to the potential production of the cow resulted in economic gains (André et al., 2010).

Technological developments, such as an on-line milk composition analyzer (Afilab, S.A.E. Afikim, Kibbutz Afikim, Israel) that measures milk fat, protein, and lactose on-line in real time at each milking with concurrent measurements of $\mathrm{BW}$, might generate information used to refine the feeding program of dairy cows (Maltz et al., 2009). We anticipated that, if beneficial, implementation of precise feeding regimens might become relevant and applicable to dairy herds that can feed early lactating cows additional concentrate individually either in the parlor, such as in rotary systems, or in robotic milking systems. Our hypothesis was that feeding cows according to individual needs (i.e., energy balance) improves production and nutrient utilization compared with feeding a single diet to all cows. The objectives of this study were to evaluate performance, nutrient digestion and excretion, and feeding behavior of early lactation dairy cows fed a TMR adjusted for energy balance using daily BW and yields of milk components for ration decision.

\section{MATERIALS AND METHODS}

All experimental procedures with cows were approved by the University of Florida Institute of Food and Agricultural Sciences Animal Research Committee.

\section{Study Design, Animals, Housing, and Feeding}

The experimental design was a complete randomized with blocks. After the 7-d pretreatment period, cows from weekly cohorts were blocked by parity (lactation 2 and lactation $>2$ ) and the ratio of milk energy secretion per kilogram of metabolic BW $\left(\mathbf{B W}^{0.75}\right)$ and, within each block, randomly assigned to 1 of the 2 treatments: a control diet or a diet that was manipulated according to the calculated energy balance of cows (precision treatment). Data collected during the pretreatment period were used for covariate adjustment during statistical analyses. The number of cows per treatment was calculated to detect a $2.0 \mathrm{~kg} / \mathrm{d}$ difference in milk yield when the expected SD of milk is $2.5 \mathrm{~kg}(\alpha=0.05$; $\beta=0.80$ ). Under these assumptions, a total of 52 cows were necessary. Because of potential attrition, 58 cows were enrolled in the study (29/treatment).

Fifty-eight multiparous, early-lactation Holstein cows from 9 weekly cohorts of 4 to 14 cows each from the University of Florida Dairy Unit were enrolled in the study. Primiparous cows were not used in the study to minimize variation in production and formation of blocks for randomization. Cows at 14 DIM were moved to the experimental pens for a 7-d pretreatment period and to acclimate to Calan gates (Calan Broadbent feeding system, American Calan Inc., Northwood, $\mathrm{NH})$. During the pretreatment period, cows were fed the control TMR (Table 1), and data collected during this week were used for covariate adjustment during statistical analysis. On d 21 postpartum, treatments were initiated; the study period lasted $16 \mathrm{wk}$, from wk 4 to 19 postpartum. Cows were housed in the same freestall barn with sand-bedded stalls, and each cow was randomly assigned to an individual feeding gate for measurements of individual feed intake. Two pens in the same barn, with the capacity for 40 cows each, were used. One pen housed 36 cows (18 blocks of cows) 
and the other housed 22 cows (11 blocks) in the study. The experiment was conducted from January to June of 2011. The experimental pens were equipped with 2 rows of fans ( 1 fan $/ 6$ linear meters), one facing the feed lane immediately above the feed bunk and the other immediately above the beds. Fans were equipped with low pressure nozzles and both fans and nozzles were activated once ambient temperature reached $20^{\circ} \mathrm{C}$.

Cows were fed twice daily, immediately after the morning milking at $0830 \mathrm{~h}$ and again at $1230 \mathrm{~h}$. The amounts of feed offered to individual cows were adjusted daily to result in at least $5 \%$ refusals, which were weighed once daily, before the morning feeding. Twice weekly, diet ingredients were sampled, dried at $55^{\circ} \mathrm{C}$, and stored for later analyses as monthly composites. The DMI of individual cows were calculated based on the $\mathrm{DM}$ of feeds measured at $105^{\circ} \mathrm{C}$.

\section{Treatments}

Diets were mixed twice daily as base mixture containing corn silage, alfalfa hay and a base-concentrate mix, and the additional grain supplement (Table 1). This base mixture contained $54 \%$ forage and was designed to meet the nutrient needs of a $650-\mathrm{kg}$ cow consuming $23 \mathrm{~kg}$ of diet DM and producing $40.0 \mathrm{~kg}$ of milk with $3.5 \%$ fat and $3.0 \%$ true protein (CPM-Dairy ver. 3.0.10 software; www.cpmdairy.net). Additional grain supplement was formulated to contain the same concentration of protein, minerals, vitamins, and additives as the base mixture TMR (Table 1). Control cows received the base mixture and an additional $12 \%$ of the total daily DM offered as the additional grain supplement (Table 1), which was split into the 2 daily feedings. Precision cows received from 0 to $25 \%$ of the total daily DM offered as additional grain supplement. The additional grain

Table 1. Ingredient and nutrient composition of the diets

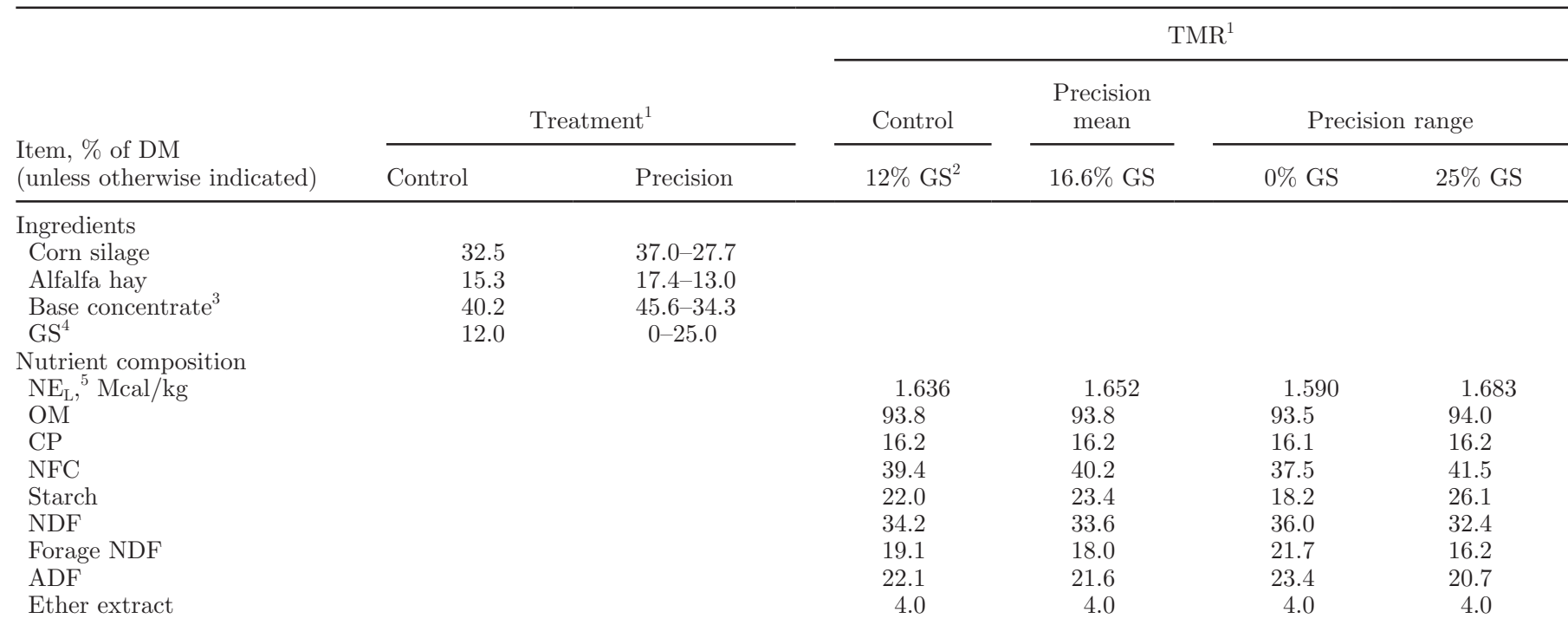

${ }^{1}$ Control $=$ cows received $12 \%$ of the diet DM as grain supplement. Precision mean = average amount of grain supplement (16.6\% of DM) offered to precision cows. Precision range $=$ range of grain supplement (0 to $25 \%$ of DM) offered to precision cows.

${ }^{2} \mathrm{GS}=$ grain supplement.

${ }^{3}$ The base concentrate contained (DM basis) 14.3\% whole cottonseed, $17.1 \%$ finely ground corn, $19.1 \%$ citrus pulp, $21.0 \%$ soybean hulls, $9.5 \%$ cooker-processed soybean meal (AminoPlus; Ag Processing Inc., Omaha, NE), and 7.6\% of a vitamin-mineral-protein premix.

${ }^{4}$ The grain supplement contained (DM basis) was $63.5 \%$ finely ground corn, $18.0 \%$ soybean hulls, $7.5 \%$ soybean meal, $7.5 \%$ cooker-processed soybean meal, and 3.5\% a vitamin-mineral-protein premix. The vitamin-mineral-protein premix added to the base concentrate and grain supplement contained (DM basis) 30.8\% blood meal, 30.5\% sodium bicarbonate, $12.0 \%$ dicalcium phosphate, $6.0 \%$ magnesium oxide, $4.8 \%$ magnesium sulfate heptahydrate, $2.9 \%$ sodium chloride, $0.12 \%$ manganese sulfate monohydrate, $0.06 \%$ zinc sulfate, $2.9 \%$ MetaSmart (Adisseo, Atlanta, GA), 0.25\% Zinpro 4-Plex (Zinpro Co., Eden Prairie, MN), 0.45\% Sel-Plex 2000 (Alltech Biotechnology, Nicholasville, KY), $0.25 \%$ Rumensin 80 (Elanco Animal Health, Greenfield, IN), and vitamin and iodine premix. Each kilogram contains $28.5 \% \mathrm{CP}, 6.3 \% \mathrm{Ca}, 1.2 \% \mathrm{P}, 3.9 \% \mathrm{Mg}, 10.5 \%$ $\mathrm{Na}, 3.1 \% \mathrm{Cl}, 587 \mathrm{mg}$ of $\mathrm{Zn}, 124 \mathrm{mg}$ of $\mathrm{Cu}, 654 \mathrm{mg}$ of $\mathrm{Mn}, 9.6 \mathrm{mg}$ of Se, $25 \mathrm{mg}$ of Co, $13 \mathrm{mg}$ of I, 131,000 IU of vitamin A, 36,000 IU of vitamin $\mathrm{D}, 1,200 \mathrm{IU}$ of vitamin $\mathrm{E}$, and $470 \mathrm{mg}$ of monensin.

${ }^{5}$ Net energy for lactation according to Weiss (1998) using analyzed feed values and calculated at 3 times maintenance. The nutrient content (mean as \% of $\mathrm{DM} \pm \mathrm{SD})$ of corn silage $(\mathrm{OM}=97.3 \pm 0.1 ; \mathrm{CP}=7.5 \pm 0.3 ; \mathrm{NFC}=47.0 \pm 1.7 ;$ starch $=30.3 \pm 2.6 ; \mathrm{NDF}=39.5 \pm 1.8 ; \mathrm{ADF}$ $=21.8 \pm 0.8 ;$ and fat $=3.4 \pm 0.3)$, alfalfa hay $(\mathrm{OM}=90.5 \pm 0.9 ; \mathrm{CP}=19.4 \pm 1.9 ; \mathrm{NFC}=27.8 \pm 1.0 ;$ starch $=1.7 \pm 0.1 ; \mathrm{NDF}=40.8 \pm 3.8 ;$ $\mathrm{ADF}=32.0 \pm 2.2 ;$ and fat $=2.6 \pm 0.2)$, base concentrate $(\mathrm{OM}=91.6 \pm 0.3 ; \mathrm{CP}=21.9 \pm 0.7 ; \mathrm{NFC}=33.5 \pm 1.0 ;$ starch $=14.7 \pm 0.4 ; \mathrm{NDF}$ $=31.2 \pm 1.0 ; \mathrm{ADF}=21.4 \pm 0.6 ;$ and fat $=5.0 \pm 0.2)$, and grain supplement $(\mathrm{OM}=95.5 \pm 0.2 ; \mathrm{CP}=16.2 \pm 1.1 ; \mathrm{NFC}=53.5 \pm 1.7 ;$ starch $=49.7 \pm 1.1 ; \mathrm{NDF}=21.8 \pm 1.1 ; \mathrm{ADF}=12.7 \pm 0.7 ;$ and fat $=3.9 \pm 0.1)$. 
supplement was thoroughly mixed with the base mixture for each individual cow.

The control diet was formulated to meet the nutrient requirements of dairy cows weighing $650 \mathrm{~kg}$, consuming $23 \mathrm{~kg}$ of DM/d and producing $41.5 \mathrm{~kg}$ of milk with $3.5 \%$ fat and $3.0 \%$ true protein (CPM-Dairy). The precision treatment received a TMR to support each individual cow's milk production and to achieve a positive energy balance of up to $5 \mathrm{Mcal} / \mathrm{d}$, but with a maximum $\mathrm{NE}_{\mathrm{L}}$ concentration of $1.68 \mathrm{Mcal} / \mathrm{kg}$ of $\mathrm{DM}$ calculated at $3 \times$ maintenance requirements (Weiss, 1998). The minimum amount of grain supplement was 0 (only the base mixture with $54 \%$ forage fed) and the maximum was $25 \%$ of the daily DM offered (TMR with $40 \%$ forage). The amount of additional grain supplement to be incorporated into the TMR of each precision cow was determined once weekly, based on calculation of energy balance from the preceding week to achieve a $+5 \mathrm{Mcal} / \mathrm{d}$. Therefore, the values for a subsequent week were projected based on the expectations of DMI and production of the preceding week. When a reduction or increase of grain supplement was between the extremes (i.e., reduce from 25 to $0 \%$ because a cow had a very positive energy balance, or increase from 0 to $25 \%$ because energy balance markedly decreased) this change was first implemented in 2 steps, the first week changing to $12 \%$ grain supplement of the total DM offered and the following week either going to 0 or $25 \%$. The TMR offered to precision cows were designed such that the changes in the ratio of forage to concentrate would be within typical acceptable ranges for highproducing dairy cows. Also, it was anticipated that the average precision cow would consume a TMR with similar nutrient composition as control cows; however, the individual decision on allocating more nutrients to higher-producing cows and less to lower-producing cows would improve performance and efficiency of nutrient utilization. The resulting calculated $\mathrm{NE}_{\mathrm{L}}$ content of the diets ranged from 1.59 to $1.68 \mathrm{Mcal} / \mathrm{d}$ calculated at 3 times the caloric maintenance intake (Weiss, 1998).

\section{BW, BCS, and Measurement of Energy Balance}

Immediately after each milking, cows were weighed on a walk-though scale (AfiWeigh, S.A.E. Afikim) located on the exit lane of the milking parlor. Body condition was scored once weekly using a 1 to 5 scale (Ferguson et al., 1994) with increments of 0.25 units by the same trained evaluator. Energy balance was calculated using daily caloric intake calculated based on DMI and the energy content of the diet at $3 \times$ maintenance (Weiss, 1998) minus the summation of the daily calories required for maintenance $\left(0.08 \times \mathrm{BW}^{0.75}\right)$ and the calories secreted as milk according to yields of fat, protein, and lactose milk yield $\times[(0.0929 \times$ fat $\%)+(0.0563 \times$ protein $\%)+(0.0395 \times$ lactose $\%)]\}$. The average energy balance during the week was used to adjust the diet of precision cows. Daily values were averaged into weekly means for statistical analyses.

\section{Measurements of Milk and Milk Components}

Cows were milked twice daily at approximately 0730 and $1930 \mathrm{~h}$ and individual yield of milk (AfiFlo milk meters, S.A.E. Afikim), concentrations of fat, true protein, and lactose (AfiLab on-line real-time milk analyzer, S.A.E. Afikim) were recorded by the Afikim milking system. The AfiLab system was calibrated once monthly with data on milk composition from 450 cows analyzed by the Southeast DHIA laboratory in Bellview, FL. Concentrations of milk components from each milking were used to calculate the daily yields of fat, protein, and lactose after adjusting for milk production during each milking. The $3.5 \%$ FCM yield was calculated as $[(0.4324 \times$ milk yield $)+(16.218 \times$ milk fat yield)] (NRC, 2001). The ECM yield was calculated as $[(0.3246 \times$ milk yield $)+(12.86 \times$ fat yield $)+(7.04$ $\times$ protein yield)] (NRC, 2001). Daily values were averaged into weekly means for statistical analyses.

\section{Analyses of Dietary Ingredients}

Dried monthly composite samples of corn silage, alfalfa hay, base concentrate, and additional grain supplement were ground to pass a 1-mm screen of a Wiley mill (Thomas Scientific, Swedesboro, NJ). Samples were then analyzed for $\mathrm{DM}\left(105^{\circ} \mathrm{C}\right.$ for $\left.12 \mathrm{~h}\right), \mathrm{OM}$ $\left(512^{\circ} \mathrm{C}\right.$ for $8 \mathrm{~h}$ ), and sequential analysis of NDF using a heat stable $\alpha$-amylase and ADF (Van Soest et al., 1991) with the Ankom Fiber Analyzer system (Ankom Technology, Macedon, NY), and for N using an automated quantitative combustion digestion method (Elementar Analysensysteme, Elementar Americas Inc., Mt. Laurel, NJ). The energy density of the diet was estimated using analyzed feed values and calculated at $3 \times$ maintenance intake (Table 1; Weiss, 1998).

\section{Blood Sampling and Analyses}

Blood ( $\sim 8 \mathrm{~mL})$ was sampled at wk 6 and 13 postpartum from cows in the first 19 blocks enrolled in the study by puncture of the coccygeal vessels into evacuated tubes containing $\mathrm{K}_{2}$ EDTA (Vacutainer, Becton Dickinson, Franklin Lakes, NJ). Two blocks were incomplete because 2 precision cows left the study before the day of sampling. Therefore, samples from 36 cows (19 controls and 17 precision) were analyzed for both sampling days. Samples were collected at 2 -h intervals 
starting at $0700 \mathrm{~h}$ (before the morning milking and feeding) and finishing before the evening milking for a period of $12 \mathrm{~h}$. Thus, a total of 7 samples were collected per cow within each week. Blood tubes were placed in ice and transported to the laboratory within $4 \mathrm{~h}$ and were centrifuged at $3,000 \times g$ for $15 \mathrm{~min}$ at $4^{\circ} \mathrm{C}$ for plasma separation. Plasma was frozen at $-25^{\circ} \mathrm{C}$ for later analyses. Concentrations of glucose (Bran and Luebbe Industrial Method 339-19; Gochman and Schmitz, 1972) and urea N (Bran and Luebbe Industrial Method 339-01; Marsh et al., 1965) were analyzed using an autoanalyzer (Technicon Instruments Corp., Tarrytown, NY).

\section{Nutrient Analyses and Apparent Total-Tract Digestibility}

At the beginning of wk 9 postpartum, the same 19 blocks of cows used for blood sampling were dosed orally twice daily with a gelatin capsule containing 10 $\mathrm{g}$ of $\mathrm{Cr}_{2} \mathrm{O}_{3}$ (20 g/cow per day), which was used as an indigestible marker to estimate total-tract apparent digestibility of DM, OM, CP, ADF, and NDF by the marker ratio technique (Schneider and Flatt, 1975). Cows were dosed for $12 \mathrm{~d}$ and TMR and individual orts were sampled once daily for the last $5 \mathrm{~d}$ of $\mathrm{Cr}_{2} \mathrm{O}_{3}$ dosing. Fecal samples were collected twice daily for the last 5 $\mathrm{d}$ after the morning and evening milkings at 12 -h intervals. Samples of feces, TMR, and orts were composited for the 5-d collection period for individual cows, dried in a forced-air oven at $55^{\circ} \mathrm{C}$ for $96 \mathrm{~h}$, had moisture loss recorded, and were then ground to pass a 1-mm screen of a Wiley mill (Thomas Scientific). Samples were analyzed for $\mathrm{Cr}$ in feces by atomic absorption spectrophotometry using a Perkin Elmer 5000 atomic absorption spectrometer (Perkin Elmer, Wellesley, MA) according to Williams et al. (1962). Samples of TMR, orts, and feces were also analyzed for their content of DM $\left(105^{\circ} \mathrm{C}\right.$ for $12 \mathrm{~h})$, OM $\left(512^{\circ} \mathrm{C}\right.$ for $\left.8 \mathrm{~h}\right)$, sequential analysis of NDF using a heat stable $\alpha$-amylase and ADF (Van Soest et al., 1991) with the Ankom Fiber Analyzer system (Ankom Technology) and N using an automated quantitative combustion digestion method (Elementar Analysensysteme, Elementar Americas Inc.).

\section{Collection and Analyses of Rumen Fluid}

Rumen fluid was collected from 55 cows through rumenocentesis performed by puncture of the left ventral region of the abdomen using a disposable sterile needle (18 gauge, $12 \mathrm{~cm}$ ) during wk 10 postpartum, at 66 DIM. Two of the 58 cows were not sampled because they left the study before the day of sampling, and 1 cow had a sample lost. The rumen fluid was collected between
6 and $7 \mathrm{~h}$ after the morning feeding. Approximately $10 \mathrm{~mL}$ of rumen fluid was collected, the $\mathrm{pH}$ measured immediately, and then acidified with $50 \%$ sulfuric acid to a $\mathrm{pH}$ below 2 and then centrifuged at 5,400 $\times g$ for $20 \mathrm{~min}$. The supernatant was collected and frozen at $-20^{\circ} \mathrm{C}$ until further analysis of VFA concentration. The fluid was thawed, centrifuged at $4^{\circ} \mathrm{C}$ and 21,500 $\times g$ for $20 \mathrm{~min}$, and the supernatant was analyzed for concentrations of lactate and VFA using the method of Canale et al. (1984) by HPLC (L7485, Hitachi, Tokyo, Japan) fitted with a UV detector (Spectroflow 757, ABI Analytical Kratos Division, Ramsey, NJ).

\section{Collection and Analyses of Urine Samples and Estimation of Microbial N Flow}

Urine was sampled from the same 19 blocks of cows used for blood sampling and digestibility analyses. Samples were collected at 5 to $6 \mathrm{~h}$ after the morning feeding in 3 consecutive days during the last $3 \mathrm{~d}$ of fecal collection for digestibility, on wk 10 postpartum. The perineal area was massaged until a clean and copious stream of urine was obtained. Samples were acidified to $\mathrm{pH}<4$ using $5 \mathrm{M}$ of $\mathrm{HCl}$ and then frozen at $-20^{\circ} \mathrm{C}$. Urine samples were thawed and analyzed individually for N (Elementar Analysensysteme, Elementar Americas Inc.), creatinine (colorimetric method - Arbor Assays kit \# K002-H1, Arbor Assays, Ann Arbor, MI), and uric acid by fluorescence-based method (Cayman Chemical kit \# 700320, Cayman Chemical, Ann Arbor, MI). Urinary creatinine has been validated as a marker to estimate urine volume (Valadares et al., 1999; Chizzotti et al., 2008). Urinary purine derivatives are commonly used to estimate microbial $\mathrm{N}$ flow to the duodenum (Chizzotti et al., 2008; Gehman and Kononoff, 2010). Urine daily creatinine excretion was assumed at $29 \mathrm{mg} / \mathrm{kg}$ of BW (Valadares et al., 1999) and it was used to estimate the total daily urinary volume. Microbial N flow was calculated using the estimates of purine derivative excretion according to Chen and Gomes (1992).

\section{N Balance}

Nitrogen balance was calculated using the same cows sampled for diet digestibility and urinary $\mathrm{N}$ excretion by calculating each cow's daily $\mathrm{N}$ intake, and outputs of fecal, urinary, and milk N. Manure N was calculated as the sum of fecal and urinary $\mathrm{N}$. Retained $\mathrm{N}$ was calculated as $\mathrm{N}$ intake minus the sum of manure and milk N. Productive N was calculated as the sum of milk and retained $\mathrm{N}$.

\section{Feeding Behavior}

Feeding behavior of all cows was evaluated once during the experiment during 2 consecutive days at the 
beginning of the wk 13 postpartum maintaining the usual feeding routine of twice daily. Cows were observed every $5 \mathrm{~min}$ for $12 \mathrm{~h}$ each day starting immediately after the morning milking until the end of the evening milking. The location and activity of each cow was recorded as ruminating standing, ruminating lying in the stall, standing only, lying only, eating, and drinking. Each observation was assumed to last $5 \mathrm{~min}$, which was the interval between observations. Chewing was considered as the summation of rumination and eating. The number of eating, lying, and chewing bouts, duration of each meal, total time eating, total time ruminating only, and total time chewing were calculated. Concurrently, a sample of feed $(\sim 300 \mathrm{~g})$ was collected immediately after morning feeding and before cows began eating, and again at 3,6,9, 12, and $24 \mathrm{~h}$ later and screened to determine particle size distribution of the diet of each cow using the 4 -sieve $(<1.18 \mathrm{~mm}, 1.18$ to $8.0 \mathrm{~mm}, 8.0$ to $19.0 \mathrm{~mm}$, and $>19.0 \mathrm{~mm}$ ) Penn State Particle Separator (Kononoff et al., 2003). Feed left in the bunk of each cow was weighed at 12 and $24 \mathrm{~h}$ after feeding and the DMI at both times were calculated. The DM, OM, and NDF contents of the diet offered and refused at $24 \mathrm{~h}$ of each cow were analyzed and the NDF consumed was computed as total NDF, as well as using NDF with particles $\geq 1.18 \mathrm{~mm}$ or $\geq 8.0 \mathrm{~mm}$ as cut-points for physically effective NDF of offered and refused.

\section{Statistical Analyses}

Two cows from the precision treatment and 1 control cow left the study before the completion of the 16-wk experimental period. The 2 precision cows left the study on wk 8 and 12 postpartum because of paratuberculosis and bovine lymphosarcoma. The control cow left the study on wk 9 postpartum because of lameness. Data from all 58 cows were included in the statistical analyses, including those 3 cows up to the day they left the study.

Data were analyzed using the GLIMMIX procedure of SAS version 9.2 (SAS/STAT, SAS Institute Inc., Cary, NC) fitting either Gaussian (continuous data) or Logistic (binary data) distributions. Distributions of the residuals of continuous data were tested for normality and data were transformed when appropriate using a link function in SAS and ilink function to backtransform the LSM and SEM. The Kenward-Roger method was used to calculate the denominator $\mathrm{df}$ to approximate the $\mathrm{F}$ tests in the mixed models.

Outcomes with repeated measurements within the same cow were analyzed with models that included the fixed effects of block, pretreatment covariate value, treatment (control vs. precision), parity (2 vs. $>2$ ), time (hour, day, or week), the interactions between treatment and parity, treatment and time, parity and time, and treatment and parity and time. Cow nested within treatment by parity was the random error for test of treatment effects. The covariance structure with the smallest Bayesian information criterion from the fit statistics parameters was chosen for each analysis performed. Model fitting was evaluated using the fit statistics. Data on feeding behavior were analyzed with the random effects of cow nested within treatment and hour relative to feeding nested within day of observation. Outcomes with a single measurement within experimental unit (rumen fluid parameters and digestibility coefficients) were analyzed with the effects of block, treatment, parity, and interaction between treatment and parity.

Additional analyses were performed for digestibility, rumen parameters, and $\mathrm{N}$ metabolism with the proportion of TMR as grain supplement as a covariate in the statistical models. The idea was to determine if treatment responses were caused by changes in the amount of grain supplement provided to cows. The statistical models were the same described before, but with the percentage of the TMR as grain supplement included as covariate.

Least squares means and proportions are reported. Treatment differences with $P \leq 0.05$ were considered statistically significant, whereas statistical tendencies to differences were accepted if $0.05<P \leq 0.10$.

\section{RESULTS}

\section{Lactation Performance}

Because the diet of precision cows was formulated according to energy balance, the proportion of concentrates in the ration consumed by them was greater $(P$ $<0.01)$ than that of control cows from wk 3 to 12 postpartum (Figure 1A). Because the caloric density of the diet was greater for precision than control, and precision cows had a $0.7 \mathrm{~kg} / \mathrm{d}$ numerical increase in DMI, caloric intake of precision cows was greater $(P$ $<0.05$ ) between wk 4 and 10 postpartum (Figure 1B). Grain supplement allocation as percentage of the diet of precision cows was maximal at wk 5 postpartum and gradually decreased until it was equal to that of controls at wk 13 postpartum. The difference in concentrate intake between treatments was maximal at wk 7 postpartum, $2.4 \mathrm{~kg} / \mathrm{d}$ more for precision than control cows in spite of similar DMI. For the entire study, concentrate intake averaged $0.86 \mathrm{~kg} / \mathrm{d}$ more for precision than control cows. In similar fashion, the proportion of precision cows receiving a TMR containing more concentrates than the control TMR was over $90 \%$ at 
wk 5 and gradually declined until wk 16 postpartum, when the proportions of precision cows receiving the grain supplement above and below the control TMR became similar (Figure 2). This greater proportion of concentrates in the first $13 \mathrm{wk}$ postpartum increased $(P$ $<0.01$ ) the calculated $\mathrm{NE}_{\mathrm{L}}$ of the diet offered (Table 2 ) because the grain supplement had less fiber and more starch (Table 1), thus greater caloric content than the control TMR. The DMI of cows did not differ between treatments (Table 2) and it increased gradually to peak at wk 14 postpartum, when cows in both treatments were consuming an average of $25.7 \mathrm{~kg} / \mathrm{d}$.

The milk production increased $(P<0.01) 3.3 \mathrm{~kg} / \mathrm{d}$ for precision compared with control cows (Table 2), and this response was observed starting at wk 4 postpartum (Figure 3A). Similarly, precision cows produced 3.2 and $2.8 \mathrm{~kg} / \mathrm{d}$ more $3.5 \%$ FCM and ECM, respectively, than control cows (Table 2). The concentrations of fat, true protein, and lactose in the milk of cows were not affected by treatment, although they all changed $(P<$ 0.01 ) with week postpartum. Nevertheless, because of the increased production with precision feeding, cows in the precision treatment produced more $(P<0.01)$ fat, true protein, and lactose.

\section{Production Efficiency and Energy Balance}

The conversion of DMI into ECM was $4.1 \%$ greater $(P=0.02)$ for precision than control cows (Table 3 ). Most of this difference was observed after wk 10 postpartum, when precision cows had a $7.1 \%$ greater feed efficiency (Figure 3B). The caloric content of milk did not differ between treatments and averaged 0.66 $\mathrm{Mcal} / \mathrm{kg}$; however, because precision cows produced more milk, the daily $\mathrm{NE}_{\mathrm{L}}$ secreted as milk was greater $(P<0.01)$ for precision than control cows $(30.0 \pm$ 0.4 vs. $27.9 \pm 0.4 \mathrm{Mcal} / \mathrm{d}$ ). Despite the greater efficiency of milk synthesis, the proportion of consumed calories partitioned into milk synthesis was similar in both treatments. Conversely, cows in precision feeding produced more $(P=0.05)$ Mcal as milk per kilogram of $\mathrm{BW}^{0.75}$ than control cows (Table 3 ) throughout the study (Figure 4A).

The mean energy balance of cows did not differ between treatments (Table 3), and both control and precision cows reached positive energy balance at similar interval postpartum (Figure 4B). However, control cows tended to have $(P<0.10)$ and had $(P<0.05)$ greater energy balance on wk 13 and 15 and wk 16 and 17 postpartum, respectively. Despite the minor differences in energy balance as lactation advanced, the mean and changes in BW and BCS did not differ between treatments (Table 3). Cows in both treatments lost, on average, $22 \mathrm{~kg}$ of BW between wk 3 and 7 postpartum, and
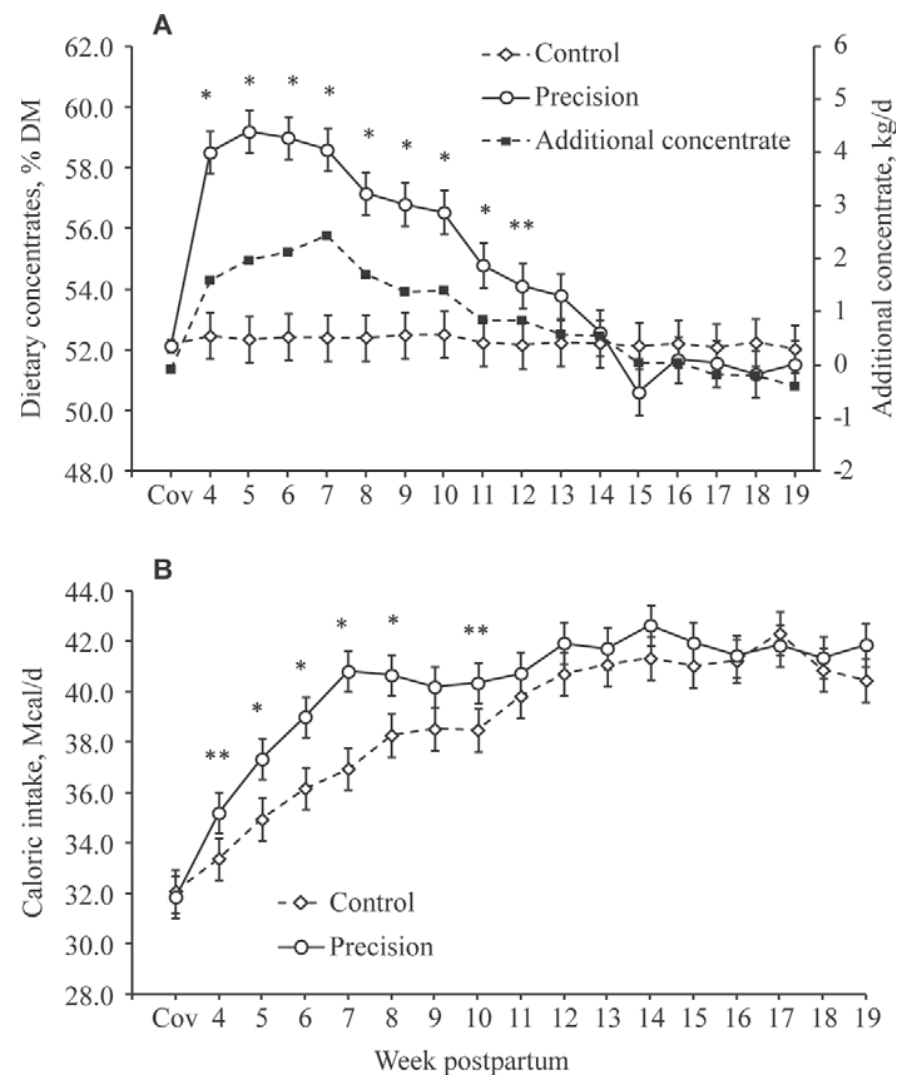

Figure 1. Percentage of the diet DM as concentrates including the additional grain supplement $(\mathrm{kg} / \mathrm{d})$ consumed by precision compared with control cows (A) and caloric intake (B) in cows receiving control or precision treatments. Cov $=$ wk 3 postpartum used for covariate adjustment of data during statistical analysis. An asterisk $(*)$ within a week indicates treatments differed $(P<0.05)$; a double asterisk $(* *)$ within a week indicates treatments tended to differ $(P<0.10)$. For panel A, precision cows consumed, on average, a diet with a greater $(P<0.01)$ percentage of concentrates than controls $(55.0 \pm 0.01$ vs. $52.3 \pm 0.01 \%)$.

began to regain weight at wk 12 postpartum (Figure $5 \mathrm{~A}$ ), whereas BCS remained relatively stable after wk 10 postpartum (Figure 5B).

\section{Plasma Metabolites}

Concentrations of urea $\mathrm{N}$ in plasma were similar between treatments in the first $12 \mathrm{~h}$ after the morning feeding at both wk 6 and 13 postpartum (Figure 6). An interaction $(P<0.01)$ between week postpartum and hour of blood sampling was observed for urea $\mathrm{N}$ concentrations. At wk 6, concentrations of urea $\mathrm{N}$ in plasma remained somewhat constant throughout the 12-h sampling period, whereas at wk 13 , concentrations increased in the first $4 \mathrm{~h}$ after feeding and gradually declined afterward.

A tendency for interaction $(P=0.07)$ between treatment and week postpartum was observed for concentra- 


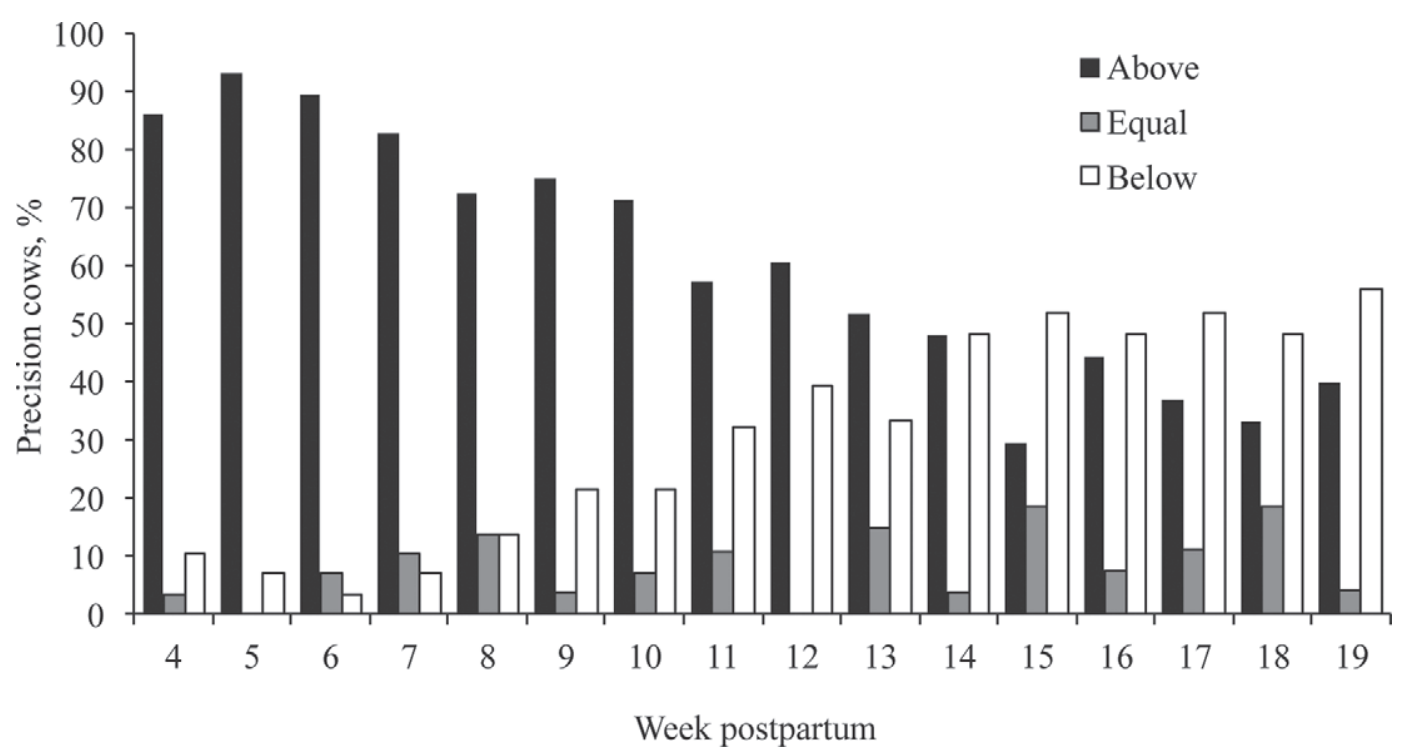

Figure 2. Proportion of precision cows receiving concentrates as a percentage of total DM offered above, equal to, or below that of controls. The control TMR always contained $52.2 \%$ concentrate, whereas the precision TMR ranged from 45.6 to $59.3 \%$ concentrate. Week 4 postpartum refers to the first week of treatments.

tions of glucose in plasma (Figure 6 ). For wk 6 postpartum, precision cows had greater $(P<0.05)$ concentrations of glucose between 2 and $10 \mathrm{~h}$ after the morning feeding. Conversely, at wk 13 postpartum, treatment did not influence concentrations of glucose in plasma.

\section{Digestibility and Rumen Parameters}

Intake of DM, OM, and $\mathrm{CP}$ and fiber fractions did not differ between control and precision cows (Table 4).
Total-tract apparent digestibility of DM, OM, CP, and NDF were not affected by treatment on wk 9 and 10 postpartum. For ADF, however, digestibility tended $(P$ $=0.06)$ to be greater for control than precision cows. When the percentage of grain supplement in the ration was used as a covariate for analyses of apparent digestibility of nutrients no differences were observed on the effects of treatment on digestibility and only minor numerical changes were observed for the coefficients of apparent digestitlity.

Table 2. Effect of precision feeding on lactation performance throughout the study

\begin{tabular}{|c|c|c|c|c|c|c|}
\hline \multirow[b]{2}{*}{ Item } & \multicolumn{2}{|c|}{ Treatment $^{1}$} & \multirow[b]{2}{*}{ SEM } & \multicolumn{3}{|c|}{$P$-value ${ }^{2}$} \\
\hline & $\begin{array}{c}\text { Control } \\
(\mathrm{n}=29)\end{array}$ & $\begin{array}{c}\text { Precision } \\
(\mathrm{n}=29)\end{array}$ & & TRT & Wk & $\mathrm{TRT} \times \mathrm{Wk}$ \\
\hline Diet $\mathrm{NE}_{\mathrm{L}}, \mathrm{Mcal} / \mathrm{kg}$ & 1.635 & 1.652 & 0.004 & $<0.01$ & $<0.01$ & $<0.01$ \\
\hline DMI, kg/d & 23.9 & 24.6 & 0.4 & 0.23 & $<0.01$ & 0.55 \\
\hline Caloric intake, Mcal/d & 39.1 & 40.6 & 0.7 & 0.10 & $<0.01$ & 0.27 \\
\hline Milk, kg/d & 41.9 & 45.2 & 0.7 & $<0.01$ & $<0.01$ & 0.87 \\
\hline $3.5 \% \mathrm{FCM}, \mathrm{kg} / \mathrm{d}$ & 40.8 & 44.0 & 0.5 & $<0.01$ & $<0.01$ & 0.90 \\
\hline ECM, kg/d & 40.2 & 43.4 & 0.5 & $<0.01$ & $<0.01$ & 0.90 \\
\hline \multicolumn{7}{|l|}{ Milk fat } \\
\hline$\%$ & 3.35 & 3.35 & 0.04 & 0.97 & $<0.01$ & 0.96 \\
\hline $\mathrm{kg} / \mathrm{d}$ & 1.40 & 1.51 & 0.02 & $<0.01$ & $<0.01$ & 0.95 \\
\hline \multicolumn{7}{|l|}{ Milk true protein } \\
\hline$\%$ & 2.93 & 2.93 & 0.02 & 0.97 & $<0.01$ & 0.62 \\
\hline $\mathrm{kg} / \mathrm{d}$ & 1.23 & 1.33 & 0.02 & $<0.01$ & $<0.01$ & 0.95 \\
\hline \multicolumn{7}{|l|}{ Lactose } \\
\hline$\%$ & 4.75 & 4.76 & 0.01 & 0.80 & $<0.01$ & 0.78 \\
\hline $\mathrm{kg} / \mathrm{d}$ & 1.99 & 2.15 & 0.04 & $<0.01$ & $<0.01$ & 0.85 \\
\hline
\end{tabular}

${ }^{1}$ Control $=$ cows received $12 \%$ of the diet DM as grain supplement. Precision $=$ cows received on average $16.6 \%$ of the diet DM as grain supplement (ranged from 0 to $25 \%$ of DM).

${ }^{2} \mathrm{TRT}=$ effect of treatment; Wk = effect of week postpartum; TRT $\times \mathrm{Wk}=$ interaction between TRT and Wk. 
Table 3. Effect of precision feeding on efficiency of nutrient utilization and energy status of dairy cows throughout the study

\begin{tabular}{|c|c|c|c|c|c|c|}
\hline \multirow[b]{2}{*}{ Item } & \multicolumn{2}{|c|}{ Treatment $^{1}$} & \multirow[b]{2}{*}{ SEM } & \multicolumn{3}{|c|}{$P$-value ${ }^{2}$} \\
\hline & $\begin{array}{c}\text { Control } \\
(\mathrm{n}=29)\end{array}$ & $\begin{array}{c}\text { Precision } \\
(\mathrm{n}=29)\end{array}$ & & TRT & Wk & $\mathrm{TRT} \times \mathrm{Wk}$ \\
\hline $\mathrm{kg}$ of $\mathrm{ECM} / \mathrm{kg}$ of DMI & 1.72 & 1.79 & 0.02 & 0.02 & $<0.01$ & 0.84 \\
\hline Milk Mcal, $\%$ of caloric intake & 82.5 & 82.1 & 1.4 & 0.95 & $<0.01$ & 0.59 \\
\hline Milk Mcal $/ \mathrm{kg}$ of metabolic BW & 0.213 & 0.227 & 0.05 & 0.05 & $<0.01$ & 0.35 \\
\hline Energy balance, Mcal/d & 1.17 & 0.46 & 0.61 & 0.40 & $<0.01$ & 0.20 \\
\hline Weeks to positive energy balance & 10.1 & 9.8 & 0.9 & 0.74 & - & - \\
\hline $\mathrm{BW}, \mathrm{kg}$ & 640.0 & 635.3 & 4.8 & 0.48 & $<0.01$ & 0.96 \\
\hline BCS, 1 to 5 & 2.65 & 2.64 & 0.07 & 0.86 & $<0.01$ & 0.45 \\
\hline
\end{tabular}

${ }^{1}$ Control $=$ cows received $12 \%$ of the diet DM as grain supplement. Precision $=$ cows received on average $16.6 \%$ of the diet DM as grain supplement (ranged from 0 to $25 \%$ of DM).

${ }^{2} \mathrm{TRT}=$ effect of treatment; Wk $=$ effect of week postpartum; TRT $\times \mathrm{Wk}=$ interaction between TRT and Wk.

Similar to digestibility, minor differences in the composition of the rumen fluid were observed on wk 10 postpartum for control and precision cows (Table 5). The mean rumen $\mathrm{pH}$, the percentage of cows with $\mathrm{pH}$
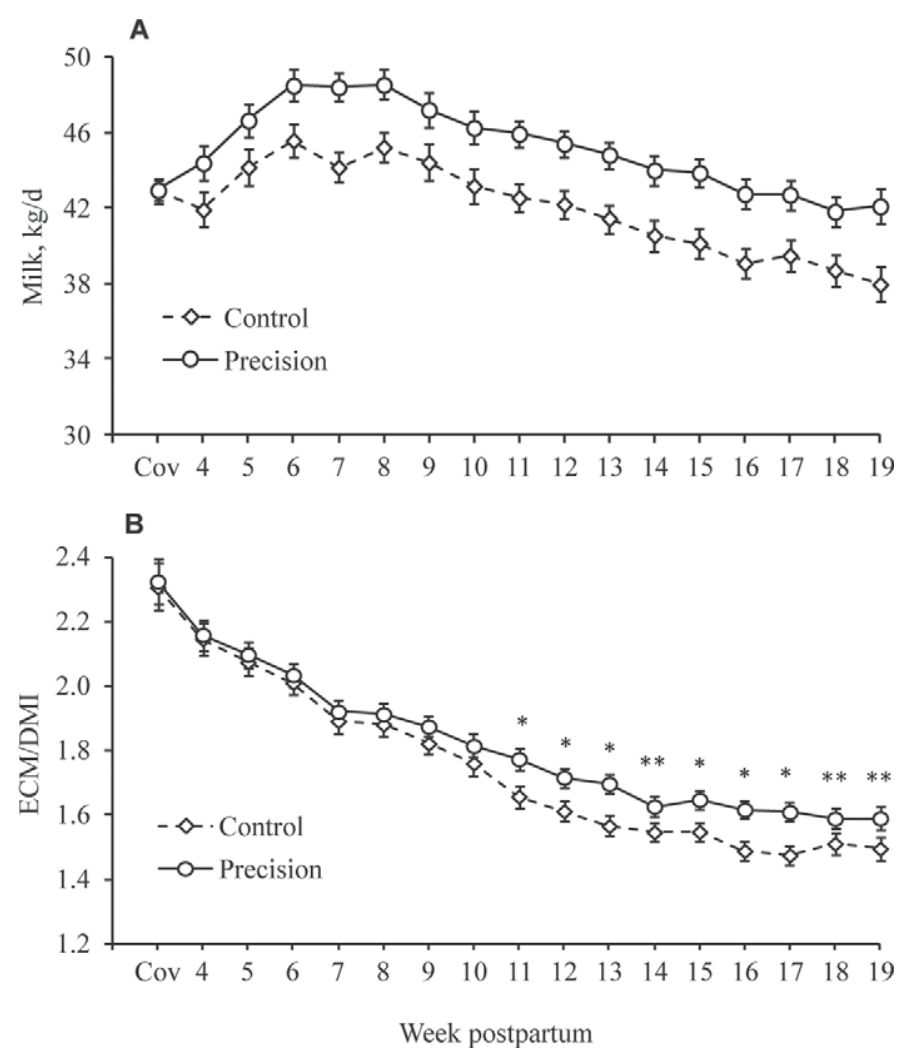

Figure 3. Milk yield (A) and efficiency of conversion of DMI into $\mathrm{ECM}(\mathrm{B})$ in cows receiving control or precision treatments. $\mathrm{Cov}=\mathrm{wk}$ 3 postpartum used for covariate adjustment of data during statistical analysis. An asterisk $\left(^{*}\right)$ within a week indicates treatments differed $(P<0.05)$; a double asterisk $\left.{ }^{* *}\right)$ within a week indicates treatments tended to differ $(P<0.10)$. For panel $\mathrm{A}$, precision cows produced more $(P<0.01)$ milk throughout the study than controls. For panel $\mathrm{B}$, precision cows had greater $(P=0.02)$ efficiency of conversion of DMI into ECM.
$<5.8$, and the mean lactate concentration did not differ between treatments. Concentrations of total VFA tended $(P=0.10)$ to be greater for control than precision because acetate and propionate concentrations tended $(P<0.10)$ to increase in cows receiving the control treatment. The concentrations of other VFA,
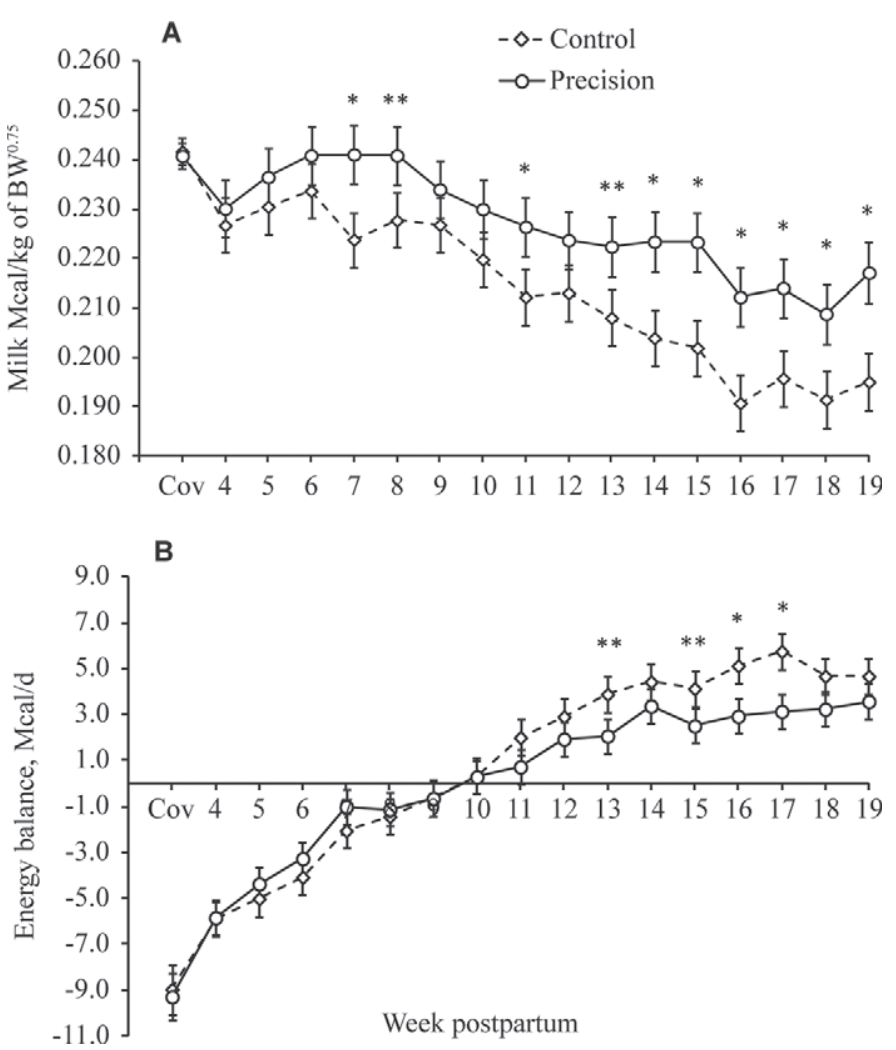

Figure 4. Milk energy secretion per kilogram of metabolic weight (A) and energy balance (B) in cows receiving control or precision treatments. Cov $=$ wk 3 postpartum used for covariate adjustment of data during statistical analysis. An asterisk $(*)$ within a week indicates treatments differed $(P<0.05)$; a double asterisk $(* *)$ within a week, treatments tended to differ $(P<0.10)$. 

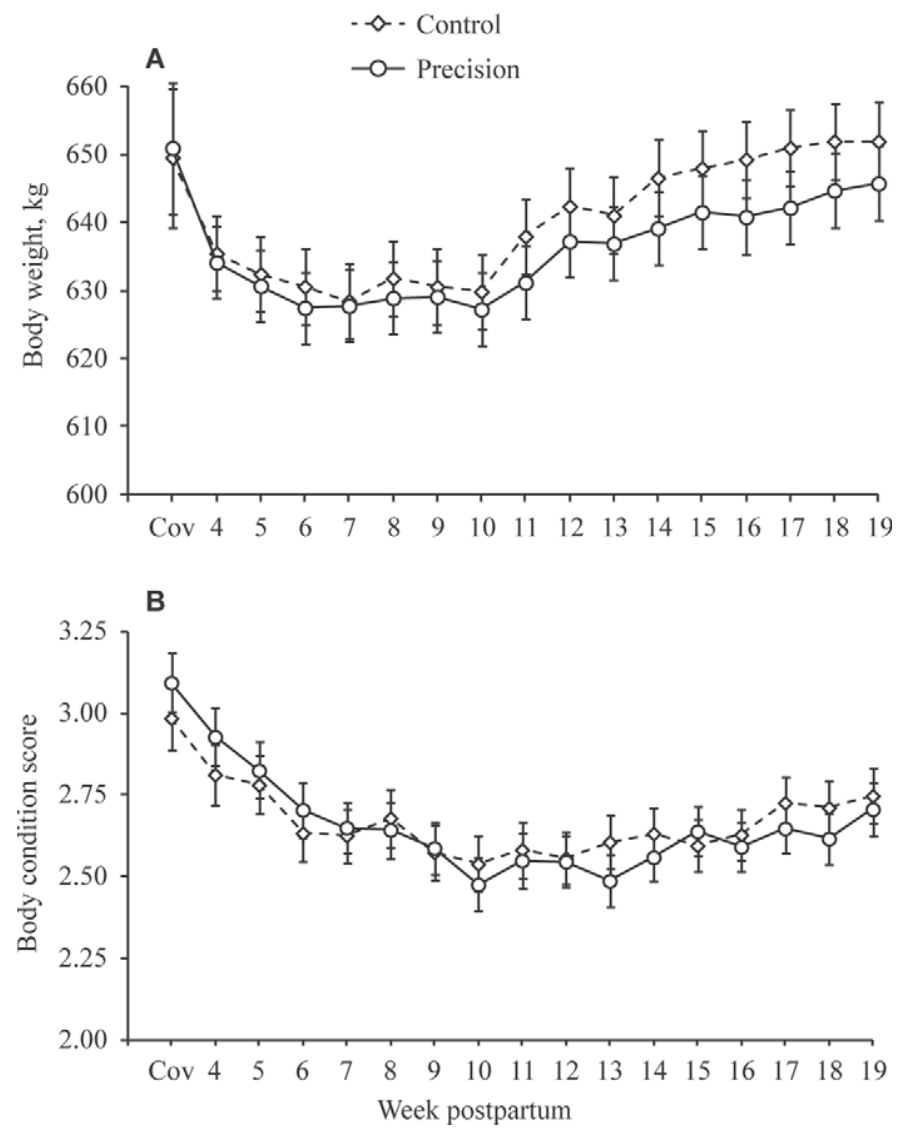

Figure 5. Body weight (A) and BCS (B) of cows receiving control or precision treatments. Cov $=$ wk 3 postpartum used for covariate adjustment of data during statistical analysis. For panel A, treatment had no effect $(P=0.48)$ on BW. For panel B, treatment had no effect $(P=0.86)$ on BCS.

the ratio of acetate to propionate, and the proportion of each VFA relative to the total molar concentration were not affected by treatment.

\section{N Metabolism and Balance}

Milk $\mathrm{N}$ as a percentage of dietary $\mathrm{N}$ intake was not different between the control and precision treatments during the 16 -wk study $(37.4 \pm 0.7$ and $37.3 \pm 0.6 \%$; $P=0.88)$. Efficiency of incorporation of dietary $\mathrm{N}$ into milk $\mathrm{N}$ declined $(P<0.01)$ from $40.1 \pm 0.01 \%$ at wk 4 postpartum to $34.8 \pm 0.01 \%$ at wk 19 postpartum. When the 36 cows used for digestibility were evaluated, excretions of urine $(31 \mathrm{~L} / \mathrm{d})$, creatinine $(161.5 \mathrm{mM} / \mathrm{d})$, and purine derivatives $(347 \mathrm{mM} / \mathrm{d})$ were not influenced by treatments (Table 6 ). Because of lack of dietary effect on purine derivatives excretion, the estimated flow of microbial $\mathrm{N}$ did not differ between control and precision cows. Similarly, when N metabolism was evaluated for the same 36 cows, the total mass of $\mathrm{N}$ consumed by cows and excreted as fecal, urinary, and milk $\mathrm{N}$ were similar between treatments (Table 6 ). On average, cows were in negative $\mathrm{N}$ balance, and the total mass of productive $\mathrm{N}$ (milk + retained) was not influenced by manipulating the diet of cows. These similar patterns of $\mathrm{N}$ intake and excretion resulted in no differences between treatments for the proportion of dietary $\mathrm{N}$ appearing as manure (fecal + urine) and productive $\mathrm{N}$ (Table 7 ).

\section{Feeding Behavior}

During the 2-d feeding behavior observation, the proportion of precision cows consuming concentrates (\% of DM) above, equal, or below that of control cows were $51.9,11.1$, and $37.0 \%$, respectively. These were similar values to those observed for the average of precision cows throughout the study (Figure 2). The percentage of forage offered did not differ between treatments (Table 7). Nevertheless, a tendency $(P<0.10)$ was observed for a greater percentage of diet DM as total NDF or NDF with particles $>1.18$ for the diet offered to precision cows compared with that of control cows (Table 7). The DMI in the first $12 \mathrm{~h}$ after feeding was greater $(P$ $=0.03)$ for control than precision cows, although the daily DMI did not differ. Total fiber intake in $24 \mathrm{~h}$ did not differ between treatments. Nonetheless, precision cows tended $(P=0.08)$ to consume $0.5 \mathrm{~kg}$ more NDF with particles $>8 \mathrm{~mm}$. This difference was attributed to the distinct pattern of feed selection observed for cows fed control or precision diets (Figure 7). Control cows selected against particles $>19 \mathrm{~mm}$ based on the interaction $(P=0.03)$ between treatment and hour relative to feeding for the proportion of particles remaining in the bunk that were $>19 \mathrm{~mm}$ particularly at 12 and $24 \mathrm{~h}$ (Figure 7A). The proportion of particles of intermediate length $(8$ to $19 \mathrm{~mm})$ decreased $(P<0.001)$ over time, but remained proportionally similar between treatments (Figure 7B). Consequently, precision cows tended $(P=$ $0.09)$ to leave and left $(P=0.01)$ over time in the bunk a larger proportion of particles between 1.18 and $8 \mathrm{~mm}$ and $<1.18 \mathrm{~mm}$, respectively (Figure 7C and D).

The time spent eating was similar between treatments and averaged $210 \mathrm{~min} / 12 \mathrm{~h}$ (Table 7). The time spent ruminating standing did not differ between treatments; however, the time spent ruminating lying was 30 min longer $(P=0.02)$ for precision than control cows. Overall, precision cows spent an extra 13 min ruminating compared with controls. Nevertheless, the total chewing time was not different between treatments and averaged $403 \mathrm{~min} / 12 \mathrm{~h}$. Time spent drinking water was the same, $11.7 \mathrm{~min} / 12 \mathrm{~h}$. Precision cows spent more $(P=0.02)$ time lying than controls. The numbers of bouts eating, chewing, or lying in $12 \mathrm{~h}$ were not different between treatments. Because control and precision cows averaged the same number of eating bouts in 12 
Table 4. Effect of precision feeding on intake of nutrients and total-tract apparent digestibility of dairy cows at wk 9 and 10 postpartum

\begin{tabular}{lcccc}
\hline & \multicolumn{2}{c}{ Treatment $^{1}$} & & \\
\cline { 2 - 3 } & $\begin{array}{c}\text { Control } \\
(\mathrm{n}=19)\end{array}$ & $\begin{array}{c}\text { Precision } \\
(\mathrm{n}=17)\end{array}$ & SEM & $P$-value \\
Item & & & & \\
Intake, kg/d & 23.5 & 25.0 & 1.0 & 0.30 \\
DM & 22.0 & 23.4 & 0.9 & 0.29 \\
OM & 3.70 & 3.94 & 0.15 & 0.27 \\
CP & 5.30 & 5.50 & 0.25 & 0.56 \\
ADF & 7.95 & 8.35 & 0.37 & 0.46 \\
NDF & & & & \\
Digestibility, \% & 64.1 & 61.7 & 1.1 & 0.17 \\
DM & 65.4 & 63.0 & 1.1 & 0.15 \\
OM & 64.3 & 63.0 & 1.4 & 0.51 \\
CP & 43.3 & 38.7 & 1.6 & 0.06 \\
ADF & 42.7 & 38.8 & 1.7 & 0.11 \\
NDF & & & & \\
\hline
\end{tabular}

${ }^{1}$ Control $=$ cows received $12 \%$ of the diet DM as grain supplement. Precision $=$ cows received on average $16.6 \%$ of the diet DM as grain supplement (ranged from 0 to $25 \%$ of DM).
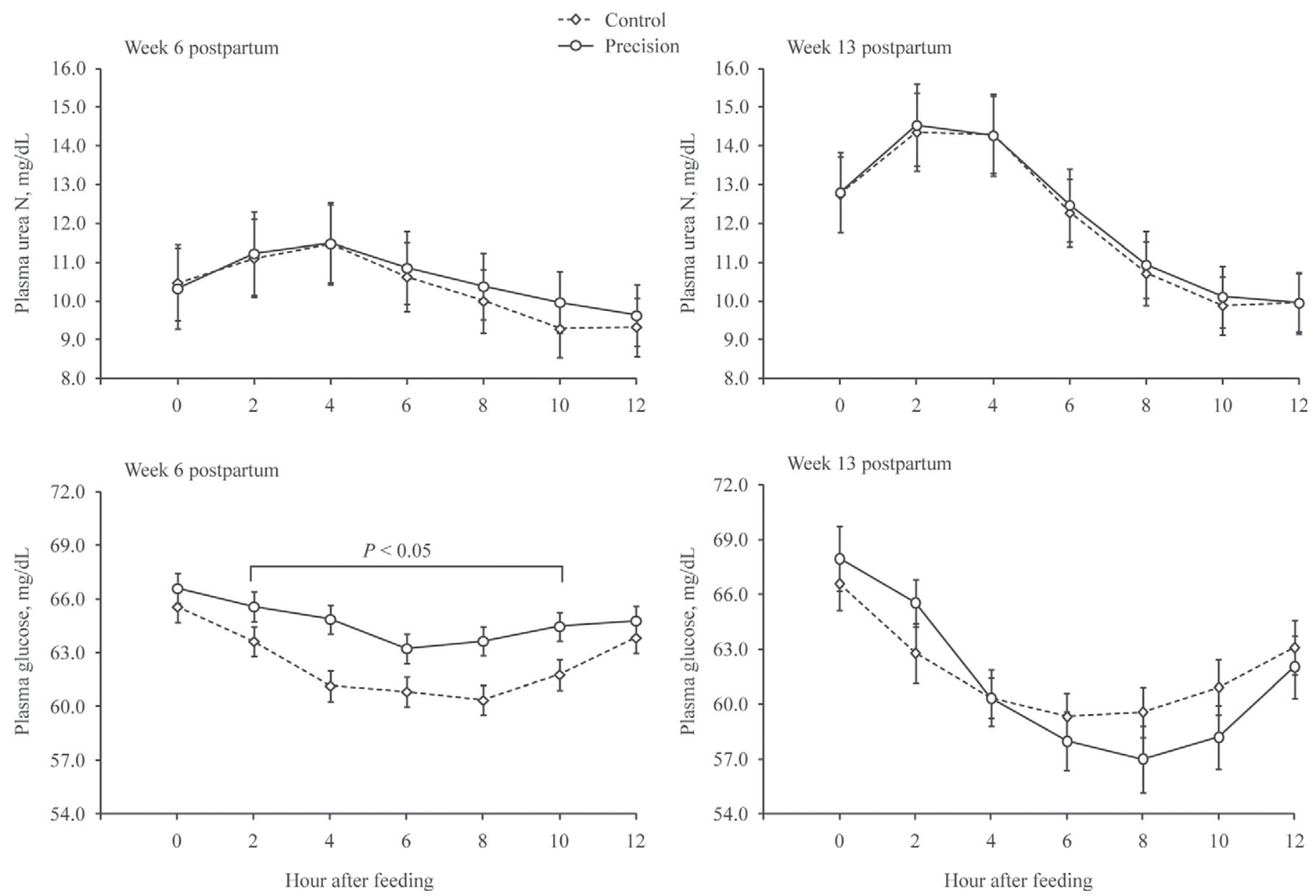

Figure 6. Plasma concentrations of urea $\mathrm{N}$ (upper panel) and of glucose (bottom panel) on wk 6 and 13 postpartum in cows receiving control or precision treatments. Blood was sampled every $2 \mathrm{~h}$ relative to the morning feeding $(\mathrm{h} 0)$. For plasma urea $\mathrm{N}$, no effect of treatment $(P=$ $0.90)$ or interactions between treatment and hour or week postpartum were observed. Hour relative to feeding $(P<0.01)$ and week postpartum $(P<0.01)$ influenced plasma urea $\mathrm{N}$ concentrations. For plasma glucose, a tendency $(P=0.07)$ for interaction between treatment and week postpartum was observed because on wk 6 , precision cows had greater $(P<0.05)$ glucose than did controls. Hour relative to feeding $(P<0.01)$ and week postpartum $(P<0.01)$ influenced plasma glucose concentrations. 
MALTZ ET AL.

Table 5. Effect of precision feeding on rumen fluid parameters of dairy cows at wk 10 postpartum

\begin{tabular}{|c|c|c|c|c|}
\hline \multirow[b]{2}{*}{ Item } & \multicolumn{2}{|c|}{ Treatment $^{1}$} & \multirow[b]{2}{*}{ SEM } & \multirow[b]{2}{*}{$P$-value } \\
\hline & $\begin{array}{c}\text { Control } \\
(\mathrm{n}=28)\end{array}$ & $\begin{array}{c}\text { Precision } \\
(\mathrm{n}=27)\end{array}$ & & \\
\hline Rumen pH & 5.96 & 6.06 & 0.19 & 0.71 \\
\hline Rumen $\mathrm{pH}<5.8, \%(\mathrm{n} / \mathrm{n})$ & $39.3(11 / 28)$ & $40.7(11 / 27)$ & - & 0.97 \\
\hline Lactate, $\mathrm{m} M$ & 2.0 & 2.1 & 0.6 & 0.88 \\
\hline \multicolumn{5}{|l|}{ VFA, $\mathrm{m} M$} \\
\hline Total & 144.8 & 125.7 & 8.0 & 0.10 \\
\hline Acetate & 82.6 & 72.3 & 4.3 & 0.10 \\
\hline Propionate & 35.9 & 29.9 & 2.4 & 0.09 \\
\hline Butyrate & 16.6 & 14.3 & 1.7 & 0.34 \\
\hline Isobutyrate & 2.1 & 2.0 & 0.1 & 0.44 \\
\hline Valerate & 4.6 & 4.4 & 0.6 & 0.76 \\
\hline Isovalerate & 3.0 & 2.8 & 0.2 & 0.30 \\
\hline Acetate:propionate & 2.46 & 2.61 & 0.10 & 0.30 \\
\hline \multicolumn{5}{|l|}{ VFA, \% of total } \\
\hline Acetate & 57.6 & 58.0 & 0.7 & 0.70 \\
\hline Propionate & 24.2 & 23.2 & 0.8 & 0.40 \\
\hline Butyrate & 11.3 & 11.4 & 0.6 & 0.91 \\
\hline
\end{tabular}

${ }^{1}$ Control $=$ cows received $12 \%$ of the diet DM as grain supplement. Precision $=$ cows received on average $16.6 \%$ of the diet DM as grain supplement (ranged from 0 to $25 \%$ of DM).

$\mathrm{h}$, but precision cows ate less in $12 \mathrm{~h}$, the meal size was smaller $(P=0.05)$ for precision than controls (Table 7$)$. Figure 8 depicts the diurnal patterns of feed intake $(\mathrm{A})$ and rumination $(\mathrm{B})$.

\section{DISCUSSION}

The goal of any feeding program is to provide the correct and balanced amount of nutrients to a cow to achieve optimum production, health, reproduction, and profitability. Distinct methods of delivering feed to dairy cattle are available, but it is a consensus that, for high-producing cows, the delivery of diets as TMR is advantageous to secure adequate intake of all ingredients of the diet and minimize risk of digestive disorders. Nevertheless, results from this experiment endorsed the hypothesis that feeding cows according to individual

Table 6. Effects of precision feeding on nitrogen metabolism in dairy cows at wk 10 postpartum

\begin{tabular}{|c|c|c|c|c|}
\hline \multirow[b]{2}{*}{ Fraction } & \multicolumn{2}{|c|}{ Treatment $^{1}$} & \multirow[b]{2}{*}{ SEM } & \multirow[b]{2}{*}{$P$-value } \\
\hline & $\begin{array}{r}\text { Control } \\
(\mathrm{n}=19)\end{array}$ & $\begin{array}{c}\text { Precision } \\
(\mathrm{n}=17)\end{array}$ & & \\
\hline Urine excretion, $\mathrm{L} / \mathrm{d}$ & 32.4 & 29.7 & 1.9 & 0.33 \\
\hline Creatinine excretion, $\mathrm{m} M / \mathrm{d}$ & 162.3 & 160.9 & 3.9 & 0.80 \\
\hline Purine derivatives, $\mathrm{m} M / \mathrm{d}$ & 362.3 & 332.0 & 22.4 & 0.48 \\
\hline Microbial N, g/d & 268.2 & 242.8 & 19.0 & 0.57 \\
\hline \multicolumn{5}{|l|}{ Mass, $\mathrm{g} / \mathrm{d}$} \\
\hline Intake of $\mathrm{N}$ & 591.1 & 630.9 & 24.6 & 0.27 \\
\hline Fecal N & 212.2 & 232.3 & 11.2 & 0.22 \\
\hline Urinary N & 216.6 & 209.9 & 7.3 & 0.53 \\
\hline Manure $^{2} \mathrm{~N}$ & 428.6 & 442.2 & 15.5 & 0.54 \\
\hline Milk N & 197.8 & 205.6 & 4.8 & 0.26 \\
\hline Retained $^{3} \mathrm{~N}$ & -35.6 & -17.0 & 15.2 & 0.40 \\
\hline Productive $^{4} \mathrm{~N}$ & 162.5 & 188.7 & 17.6 & 0.31 \\
\hline \multicolumn{5}{|l|}{ As $\%$ of $\mathrm{N}$ intake } \\
\hline Fecal N & 35.7 & 37.0 & 0.5 & 0.09 \\
\hline Urinary $\mathrm{N}$ & 38.2 & 33.1 & 2.5 & 0.16 \\
\hline Manure N & 73.9 & 70.1 & 2.7 & 0.33 \\
\hline Milk N & 34.0 & 33.4 & 1.2 & 0.76 \\
\hline Retained N & -8.1 & -2.8 & 3.4 & 0.28 \\
\hline Productive N & 26.1 & 30.0 & 2.7 & 0.33 \\
\hline
\end{tabular}

${ }^{1}$ Control $=$ cows received $12 \%$ of the diet DM as grain supplement. Precision $=$ cows received on average $16.6 \%$ of the diet DM as grain supplement (ranged from 0 to $25 \%$ of DM).

${ }^{2}$ Manure $\mathrm{N}=$ fecal $\mathrm{N}+$ urinary $\mathrm{N}$.

${ }^{3}$ Retained $\mathrm{N}=\mathrm{N}$ intake $-($ manure $\mathrm{N}+$ milk $\mathrm{N})$.

${ }^{4}$ Productive $\mathrm{N}=$ milk $\mathrm{N}+$ retained $\mathrm{N}$. 
Table 7. Effect of precision feeding on eating behavior of dairy cows ${ }^{1}$

\begin{tabular}{|c|c|c|c|c|c|c|}
\hline \multirow[b]{2}{*}{ Item } & \multicolumn{2}{|c|}{ Treatment $^{2}$} & \multirow[b]{2}{*}{ SEM } & \multicolumn{3}{|c|}{$P$-value ${ }^{3}$} \\
\hline & $\begin{array}{c}\text { Control } \\
(\mathrm{n}=28)\end{array}$ & $\begin{array}{c}\text { Precision } \\
(\mathrm{n}=27)\end{array}$ & & TRT & Day & $\begin{array}{c}\text { TRT } \\
\times \text { Day }\end{array}$ \\
\hline \multicolumn{7}{|l|}{ Diet offered, \% DM } \\
\hline Forage & 47.5 & 48.3 & 0.9 & 0.48 & 0.63 & 0.13 \\
\hline Total NDF & 36.4 & 37.3 & 0.4 & 0.10 & 0.92 & 0.27 \\
\hline $\mathrm{NDF}>1.18 \mathrm{~mm}$ & 28.6 & 29.8 & 0.5 & 0.09 & 0.08 & 0.39 \\
\hline $\mathrm{NDF}>8 \mathrm{~mm}$ & 14.5 & 15.7 & 0.6 & 0.14 & 0.96 & 0.32 \\
\hline \multicolumn{7}{|l|}{ DMI, kg } \\
\hline $12 \mathrm{~h}$ & 21.8 & 19.9 & 0.6 & 0.03 & $<0.01$ & 0.80 \\
\hline $24 \mathrm{~h}$ & 25.9 & 25.9 & 0.7 & 0.99 & 0.06 & 0.29 \\
\hline \multicolumn{7}{|l|}{ Intake $24 \mathrm{~h}, \mathrm{~kg}$} \\
\hline Total NDF & 9.4 & 9.7 & 0.3 & 0.41 & 0.18 & 0.97 \\
\hline $\mathrm{NDF}>1.18 \mathrm{~mm}$ & 7.3 & 7.7 & 0.2 & 0.24 & 0.01 & 0.86 \\
\hline $\mathrm{NDF}>8 \mathrm{~mm}$ & 3.7 & 4.2 & 0.2 & 0.08 & 0.91 & 0.69 \\
\hline Eating, $\min / 12 \mathrm{~h}$ & 213.3 & 206.4 & 7.1 & 0.49 & 0.82 & 0.45 \\
\hline \multicolumn{7}{|l|}{ Ruminating, $\min / 12 \mathrm{~h}$} \\
\hline Standing & 82.9 & 66.9 & 7.6 & 0.14 & 0.71 & 0.87 \\
\hline Lying & 103.4 & 132.8 & 8.7 & 0.02 & 0.04 & 0.53 \\
\hline Total & 186.3 & 199.8 & 7.1 & 0.18 & 0.01 & 0.34 \\
\hline Total chewing, $\min / 12 \mathrm{~h}$ & 399.6 & 406.1 & 9.5 & 0.63 & 0.02 & 0.80 \\
\hline Drinking, min/12 h & 11.7 & 11.7 & 1.0 & 0.99 & 0.01 & 0.97 \\
\hline Lying, $\min / 12 \mathrm{~h}$ & 235.6 & 273.7 & 11.6 & 0.02 & 0.12 & 0.55 \\
\hline \multicolumn{7}{|l|}{ Bouts, no. $/ 12 \mathrm{~h}$} \\
\hline Eating & 6.07 & 6.00 & 0.20 & 0.78 & 0.45 & 0.79 \\
\hline Chewing & 9.7 & 10.2 & 0.2 & 0.15 & 0.30 & 0.94 \\
\hline Lying & 3.6 & 3.9 & 0.2 & 0.25 & 0.01 & 0.55 \\
\hline Meal duration, min & 36.3 & 36.2 & 1.6 & 0.98 & 0.64 & 0.35 \\
\hline Meal size, $\mathrm{kg}$ & 3.64 & 3.33 & 0.1 & 0.05 & 0.14 & 0.63 \\
\hline
\end{tabular}

${ }^{1}$ Feeding behavior was evaluated in 2 consecutive days when cows were on average at wk $13 \pm 0.1$ postpartum. The proportion of precision cows consuming concentrates (\% DM) above, equal, or below to that of control cows were $51.9,11.1$, and $37.0 \%$, respectively.

${ }^{2}$ Control $=$ cows received $12 \%$ of the diet DM as grain supplement. Precision $=$ cows received on average $16.6 \%$ of the diet DM as grain supplement (ranged from 0 to $25 \%$ of DM).

${ }^{3} \mathrm{TRT}=$ effect of treatment; Day $=$ effect of day; TRT $\times$ Day $=$ interaction between TRT and Day.

needs, based on energy balance, improves lactation performance and conversion of diet DM into ECM.

The control diet used in the current experiment represents a typical lactating diet that was formulated to support production of $41.5 \mathrm{~kg} / \mathrm{d}$ of milk when cows consume $23 \mathrm{~kg}$ of DM/d (NRC, 2001). This was the intermediate value compared with precision cows fed the minimum or maximum amount of grain supplement. In fact, the average intake of the control cows was 23.9 $\mathrm{kg} / \mathrm{d}$ and they produced $41.9 \mathrm{~kg}$ of milk/d during the 16-wk experiment, which was similar to the levels predicted by the NRC (2001). Therefore, the NRC (2001) predicted accurately the needs of the average cow and improvements in performance would require additional DMI. The control diet contained $19.1 \%$ forage NDF, which is not likely to have limited intake because of rumen fill (Dado and Allen, 1995). When cows were fed a low-forage diet, containing $18 \%$ forage NDF, increasing rumen fill by adding rumen-inert bulk did not influence DMI (Dado and Allen, 1995). Similarly, when cows were fed a diet containing $20.7 \%$ forage NDF and starch was replaced with soybean hulls, DMI increased $2.4 \mathrm{~kg} / \mathrm{d}$ (Gencoglu et al., 2010). Conversely, overfeeding starch can limit intake because of chemical or neural signals that influence satiety and reduce meal time (Allen et al., 2009). Interestingly, compared with controls, precision cows had similar meal duration, but smaller meal size, which has been shown when cows are fed low-NDF and high-rumen-degradable starch diets (Oba and Allen, 2003).

The improvements in lactation performance were observed throughout the 16-wk experiment, although efficiency of conversion of diet DM into ECM improved mostly after wk 10 postpartum. After wk 10 postpartum, only approximately 40 to $50 \%$ of the precision cows were consuming a diet with a greater proportion of concentrates than controls, and concentrate intake during that time was similar between control and precision cows. Therefore, the improved caloric intake in the first weeks postpartum and the individual allocation of nutrients based on energy balance improved lactation performance that extended beyond the period in which the average cow in the precision treatment was consuming a more calorie-dense diet than control cows. 

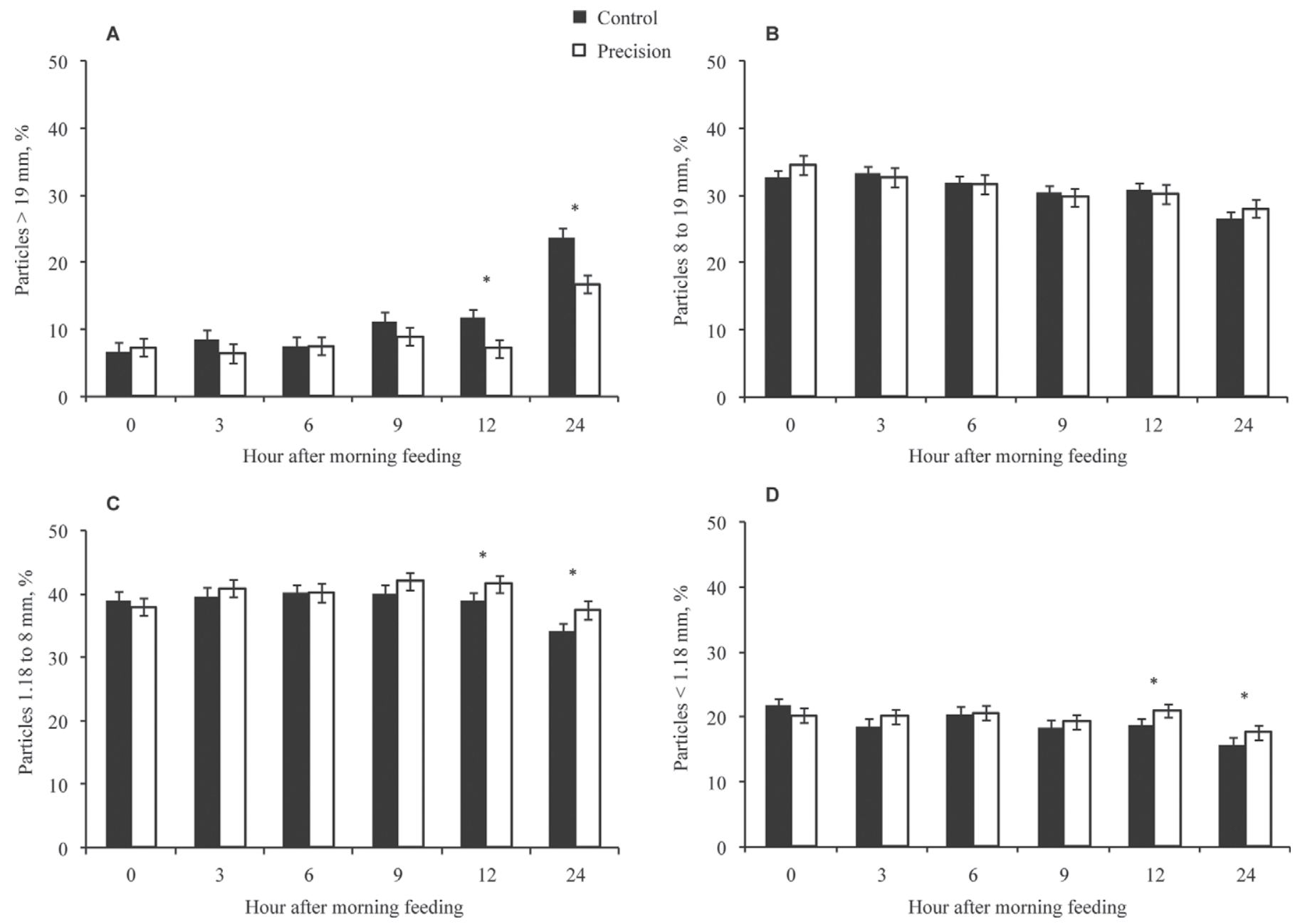

Figure 7. Distribution of particles in the diet of cows receiving control or precision treatments throughout the day measured on wk 13 postpartum. Particles size distribution was evaluated for individual cows during 2 consecutive days. For particles $>19 \mathrm{~mm}$ (panel A), effects of treatment $(P<0.05)$, hour after feeding $(P<0.001)$, and interaction between treatment and hour after feeding $(P=0.03)$ were observed. For particles of 8 to $19 \mathrm{~mm}$ (panel B), effects of treatment $(P=0.87)$, hour after feeding $(P<0.001)$, and interaction between treatment and hour after feeding $(P=0.32)$ were observed. For particles of 1.18 to $8 \mathrm{~mm}$ (panel $\mathrm{C}$ ), effects of treatment $(P=0.23)$, hour after feeding $(P<0.001)$, and interaction between treatment and hour after feeding $(P=0.09)$ were observed. For particles $<1.18 \mathrm{~mm}$ (panel D), effects of treatment $(P=0.32)$, hour after feeding $(P<0.001)$, and interaction between treatment and hour after feeding $(P=0.01)$ were observed. Asterisks $(*)$ indicate that within hour, treatments differ $(P<0.05)$.

Throughout the study, precision cows consumed an average of 1.5 Mcal of $\mathrm{NE}_{\mathrm{L}}$ more than control cows. This amount of calories is enough for an additional 2.3 $\mathrm{kg}$ of milk, which contained $0.66 \mathrm{Mcal} / \mathrm{kg}$. Because the difference in milk yield between treatments was 3.3 $\mathrm{kg} / \mathrm{d}$, the additional $1.0 \mathrm{~kg}$ cannot be explained by the average caloric intake of cows. By feeding cows according to energy balance, it is possible that the individual allocation of nutrients favored cows that were able to respond to additional concentrates, thereby producing more milk.

Interestingly, at wk 13 postpartum precision cows selected a diet in favor of longer NDF particles. This increased consumption of longer NDF likely influenced rumination patterns with longer time spent ruminating lying. Consumption of forage NDF, particularly when particles are long, stimulates cud chewing and rumination (Dado and Allen, 1995; Mertens, 1997). Mertens (1997) proposed NDF with particles $>1.18$ $\mathrm{mm}$ are physically effective. A minimum amount of physically effective NDF is needed in the diet of dairy cows to maintain rumen $\mathrm{pH}$ and milk fat content. The selection of longer particles by precision cows might have favored improvements in rumen fermentation to maintain similar rumen $\mathrm{pH}$ to that of control cows, although measurements were taken at wk 13 , when only $52 \%$ of the precision cows were consuming a diet with a greater proportion of concentrates than controls. In 

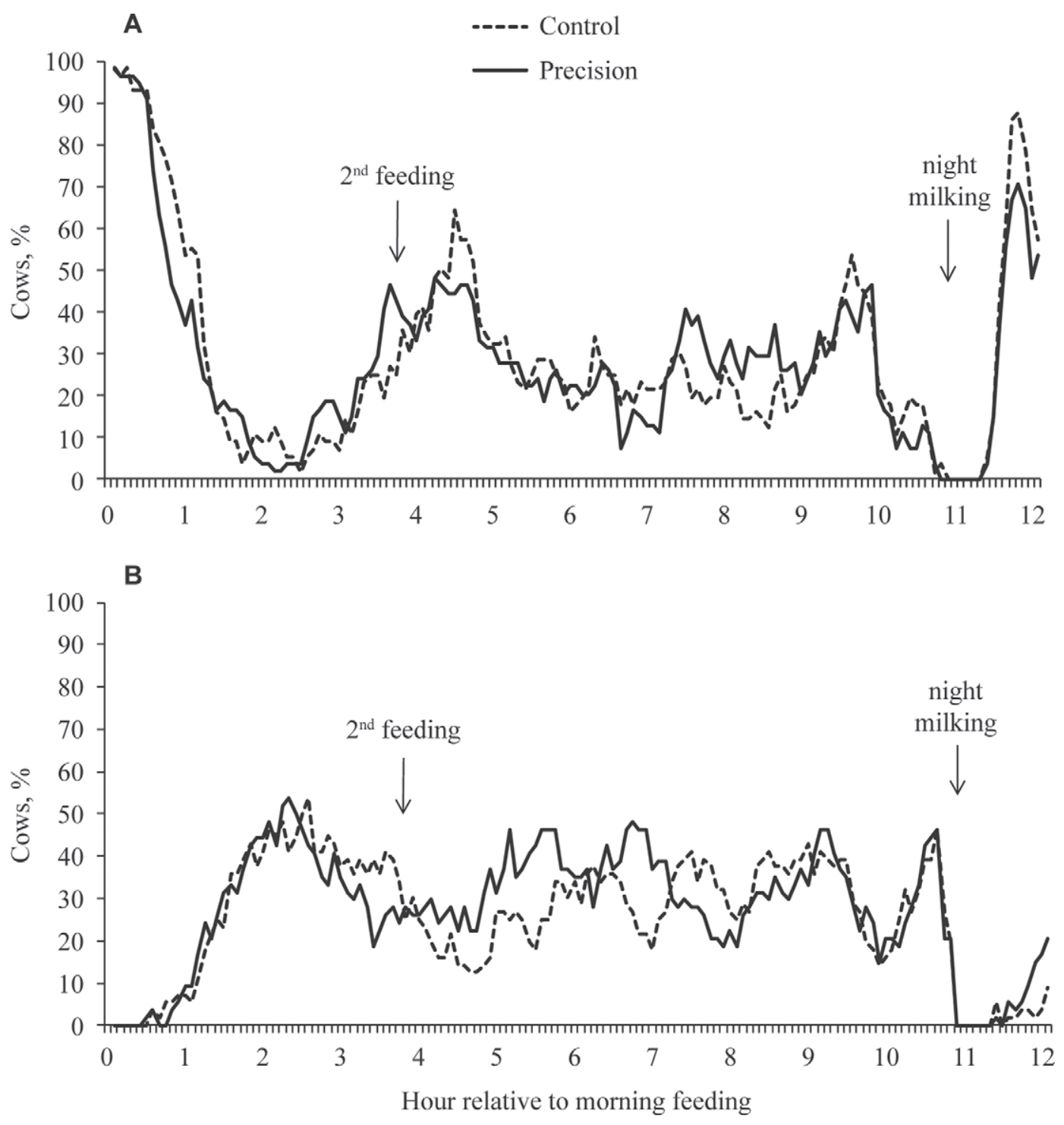

Figure 8. Proportion of cows eating (A) or ruminating (B) according to treatment and hour after the morning feeding at $0830 \mathrm{~h}(\mathrm{~h} 0)$. A second feeding was offered 3.5 to $4 \mathrm{~h}$ after the first feeding (see arrow for second feeding indicating the exact time). Cows went to the night milking approximately $11 \mathrm{~h}$ after the morning feeding (see arrow for night milking).

freestall dairies, lactating cows spend, on average, 12 $\mathrm{h}$ a day lying and $4.3 \mathrm{~h}$ eating (Gomez and Cook, 2010). A positive association has been observed between lying time and milk production (Krawczel and Grant, 2009). Although it is unknown if a cause-effect relationship exists, cows that spent more time lying on stalls also produce more milk (Krawczel and Grant, 2009).

Other methods to selectively allocate additional nutrients to lactating dairy cows are the use of automatic self-feeders or supplement cows during milking. Studies with high-producing cows in Israel have demonstrated that offering a portion of the concentrate in automatic feeders can either maintain or even increase yields of milk and milk components (Halachmi et al., 2009). When conventional starchy pellets were replaced with pellets high in digestible NDF by substituting soybean hulls for ground corn and wheat bran, increments in yields of milk, milk fat, and protein were observed in cows producing approximately $40 \mathrm{~kg}$ /day (Halachmi et al., 2009). Nevertheless, a similar response was not observed in a second experiment with cows producing approximately $35 \mathrm{~kg} /$ day (Halachmi et al., 2006). It is possible that the benefits of differential feeding of concentrates according to production on lactation performance are greater in cows of greater productive potential, or cows in early lactation, such as those in the current experiment. 
Although the precision cows received, on average, a diet with a similar $\mathrm{NE}_{\mathrm{L}}$ concentration to that of control cows, the former were fed diets with varied proportions of concentrates individually to alter the caloric content according to the energy balance of each cow. Early lactation cows experience negative nutrient balance because intake lags behind nutrient secretion in milk. Even at wk 9 postpartum cows were, on average, in negative energy and $\mathrm{N}$ balance, and this occurred in both control and precision cows. Negative $\mathrm{N}$ balance has been observed by others even in mid-lactation cows consuming diets containing 19 to $20 \% \mathrm{CP}$ (Gehman and Kononoff, 2010). In the current study, cows consumed diets containing $16.1 \% \mathrm{CP}$ and efficiency of dietary N incorporation into milk protein was high, averaging $37.4 \%$. The moderate-protein diet coupled with the high efficiency of $\mathrm{N}$ use for milk protein synthesis likely explains the moderate postprandial concentrations of urea $\mathrm{N}$ in plasma of cows, particularly at wk 6 postpartum. Also the high efficiency of $\mathrm{N}$ utilization coupled with moderate-CP diets might have masked a potential benefit of precision feeding on $\mathrm{N}$ conservation. Because diets had the same concentration of protein, but varied only in caloric density, the ability of this program to further improve $\mathrm{N}$ utilization was likely limited.

Precision cows were fed a diet with up to $1.68 \mathrm{Mcal} /$ $\mathrm{kg}$, and, in early lactation, most of them received a greater proportion of dietary concentrates than control cows. Despite improvements in lactation performance, measures of energy status were similar between treatments. In general, cows gained BW before improvements in BCS were observed. Others also observed changes in BW that preceded gains in body condition (Mizrach et al., 1998). These differences are likely related to changes in gastrointestinal fill as DMI increases. In fact, although not displayed in the current study, BW after the morning milking were generally 20 to $25 \mathrm{~kg}$ less than the BW measured immediately after the evening milking. These differences are likely related to the patterns of DM and water intakes, as cows consumed 75 to $85 \%$ of the daily DM in the first $12 \mathrm{~h}$ after the morning feeding.

Concentrations of glucose in plasma increased in precision compared with control cows at wk 6 , but not at wk 13 postpartum. This difference likely reflects the increased concentrate intake by precision cows in the first weeks postpartum, particularly more starch, which is known to influence plasma glucose (Oba and Allen, 2003). Interestingly, precision cows had similar digestibility of nutrients and rumen VFA concentrations compared with controls. Part of this response might reflect when measurements were taken, after wk 9 postpartum, when intake of concentrates by precision cows reflected the average cow in that treatment, and was only slightly different than controls. It was anticipated that feeding a diet higher in concentrates would improve digestibility of DM and OM compared with cows fed more forage and influence rumen VFA profile and estimated microbial protein flow. Nonetheless, these measures remained mostly unaltered by treatments. Although the average precision cow consumed approximately $0.86 \mathrm{~kg} / \mathrm{d}$ more concentrate in place of forage than control cows, this was not sufficient to influence rumen parameters and diet digestibility. Also, because precision cows were fed according to each cow's energy balance, the average value for the precision treatment might not necessarily capture the individual responses of the cows. Digestibility of NDF was numerically reduced, and that of ADF tended to be reduced in precision cows. It is possible that the additional starch fed to precision cows compromised rumen cellulose digestion. When soyhulls replaced starch, diet DM and NDF digestibility improved despite the additional 9\% increase in DMI by cows (Gencoglu et al., 2010).

Although the study lasted for the first 19 wk postpartum, no indication that the response to precision feeding declined over time was observed. Because precision cows had their diets adjusted to achieve 5 Mcal of $\mathrm{NE}_{\mathrm{L}}$ positive energy balance, it is likely that, as the lactation progressed, control cows would be in a better energy balance and gain more BW than precision cows. At wk 19 postpartum, control cows were consuming 0.5 $\mathrm{kg}$ more concentrate than precision cows, despite having lower milk production. This clearly indicates that, by feeding cows a single diet, partition of nutrients might favor body reserves in place of production. Highproducing cows that are fed diets with limited nutrient density might not achieve full production potential if they do not increase DMI to compensate for the high nutrient secretion in milk. Conversely, less productive cows gaining BW might require less nutrient dense diets. Therefore, either individual supplementation or multiple diets are needed to accommodate the differences in nutrient requirements of cows with varying production potential.

The challenge to implementing multiple feeding groups is how to determine what cows will respond to a more nutrient dense ration. Although diets were fed as TMR in the current study, it is possible to individually supplement cows either through automatic feeders or by the use of supplementation during milking. The inability to measure individual feed intake in cows should not prevent the attempt to apply this strategy. André et al. (2011) developed mathematical models to estimate milk production responses to concentrate intake and suggested that algorithms be incorporated to determine the daily individual optimal allowance of concentrates to optimize production. The ability to weigh cows daily 
after milking provides insights on how nutrients are partitioned to decide on the need to reduce or increase dietary nutrient density. Also, development of methods to rank cows, such as milk energy secretion per $\mathrm{kg}$ of $\mathrm{BW}^{0.75}$ with the use of real-time on-line milk composition, might offer an alternative to select cows that might respond to additional supplementation. Spahr et al. (1993) suggested classifying cows based on their lactation potential using 3.5\% FCM relative to $\mathrm{BW}$ in the first weeks postpartum as a measure to distinguish cows relative to their potential to respond to different feeding strategies. In fact, Maltz et al. (1992) observed that milk yield per unit of BW was better than milk yield alone to refine individual cow supplementation by automatic feeders. Developing methods to identify cows that might respond to additional supplementation beyond what the TMR offers might allow for nutritional strategies for precise feeding to be incorporated in a production setting when daily DMI of individual cows is not available. Evidence that implementation of differential feeding of cows by automated feeding improves profitability by adjusting the nutrient supply to the needs of the cow has been noted (André et al., 2010, Maltz et al., 2009). In large herds, in which the ability to supplement cows individually might not be feasible, alternative strategies such as multiple groups of cows with specifically formulated diets might be necessary to minimize under and overfeeding during the lactation.

\section{CONCLUSIONS}

Individual allocation of additional concentrates by altering the amount of additional grain supplement fed to cows improved lactation performance and efficiency of DM conversion into ECM compared with feeding a single TMR to all cows. The response to precision feeding persisted even when the mean caloric intake was similar between treatments. The improvements in lactation performance and feed conversion ratio did not result in altered urinary and fecal $\mathrm{N}$ excretions. It is possible that the moderate dietary protein content and the high efficiency of dietary $\mathrm{N}$ incorporation into milk $\mathrm{N}$, which resulted in negative $\mathrm{N}$ balance, might have masked the potential benefits of dietary manipulation on $\mathrm{N}$ conservation. The improvements in lactation performance observed with precision feeding did not compromise measures of energy status, even when the caloric intake was similar between treatments and production of milk remained higher for precision than control cows. Future research should focus on methods to incorporate these concepts in large dairy herds to determine if individual allocation of supplements, based on BW and online assessment of yields of milk com- ponents, improves performance when measurements of individual cow DMI are not feasible.

\section{ACKNOWLEDGMENTS}

The authors thank Eric Diepersloot and the staff of the University of Florida Dairy Unit, and the help from the University of Florida (Gainesville) students Eduardo S. Ribeiro, Fábio S. Lima, Jae-Hyeong Shin, Natalia Martinez, and Rafael Bisinotto. Our appreciation is extended to Alon Arazi and Itay Rejzewski of S.A.E. Afikim ((Kibbutz Afikim, Israel) for technical support, comments and discussions during the conduct of the study. We thank S.A.E. Afikim of Israel for partial financial support of E. Maltz.

\section{REFERENCES}

Aguerre, M. J., M. A. Wattiaux, J. M. Powell, G. A. Broderick, and C. Arndt. 2011. Effect of forage-to-concentrate ratio in dairy cow diets on emission of methane, carbon dioxide, and ammonia, lactation performance, and manure excretion. J. Dairy Sci. 94:30813093.

Allen, M. S., B. J. Bradford, and M. Oba. 2009. Board Invited Review: The hepatic oxidation theory of the control of feed intake and its application to ruminants. J. Anim. Sci. 87:3317-3334.

André, G., P. B. M. Berentsen, G. Van Duinkerken, B. Engel, and A. G. J. M. Oude Lansink. 2010. Economic potential of individual variation in milk yield response to concentrate intake of dairy cows. J. Agric. Sci. 148:263-276.

André, G., B. Engel, P. B. M. Berentsen, G. Van Duinkerken, and A. G. J. M. Oude Lansik. 2011. Adaptive models for online estimation of individual milk yield response to concentrate intake and milking interval length of dairy cows. J. Agric. Sci. 149:769-781.

Canale, A., M. E. Valente, and A. Ciotti. 1984. Determination of volatile carboxylic acids (C1-C5) and lactic acid in aqueous acid extracts of silage by high-performance liquid chromatography. J. Sci. Food Agric. 35:1178-1182.

Chen, X. B., and M. J. Gomes. 1992. Estimation of microbial protein supply to sheep and cattle based on urinary excretion of purine derivatives - An overview of the technical details. International Feed Resources Unit Occ. Publ. Rowett Research Institute, Bucksburn Aberdeen, UK.

Chizzotti, M. L., S. C. Valadares Filho, R. F. D. Valadares, F. H. M. Chizzotti, and L. O. Tedeschi. 2008. Determination of creatinine excretion and evaluation of spot urine sampling in Holstein cattle. Livest. Sci. 113:218-225.

Coffey, M. P., G. Simm, and S. Brotherstone. 2002. Energy balance profile for the first three lactations of dairy cows estimated using random regression. J. Dairy Sci. 85:2669-2678.

Dado, R. G., and M. S. Allen. 1995. Intake limitations, feeding behavior, and rumen function of cows challenged with rumen fill from dietary fiber or inert bulk. J. Dairy Sci. 78:118-133.

Ferguson, J. D., D. T. Galligan, and N. Thomsen. 1994. Principal descriptors of body condition score in Holstein cows. J. Dairy Sci. 77:2695-2703.

Gehman, A. M., and P. J. Kononoff. 2010. Nitrogen utilization, nutrient digestibility, and excretion derivatives in dairy cattle, consuming rations containing corn milling co-products. J. Dairy Sci. 93:3641-3651.

Gencoglu, H., R. D. Shaver, W. Steinberg, J. Ensink, L. F. Ferraretto, S. J. Bertics, J. C. Lopes, and M. S. Akins. 2010. Effect of feeding a reduced-starch diet with or without amylase addition on lactation performance in dairy cows. J. Dairy Sci. 93:723-732. 
Gochman, N., and J. M. Schmitz. 1972. Application of a new peroxide indicator reaction to the specific, automated determination of glucose with glucose oxidase. Clin. Chem. 18:943-950.

Gomez, A., and N. B. Cook. 2010. Time budgets of lactating dairy cattle in commercial freestall herds. J. Dairy Sci. 93:5772-5781.

Halachmi, I., E. Shoshani, R. Solomon, E. Maltz, and J. Miron. 2006. Feeding of pellets rich in digestible neutral detergent fiber to lactating cows in an automatic milking system. J. Dairy Sci. 89:3241-3249

Halachmi, I., E. Shoshani, R. Solomon, E. Maltz, and J. Miron. 2009. Feeding soyhulls to high-yielding dairy cows increased milk production, but not milking frequency, in an automatic milking system. J. Dairy Sci. 92:2317-2325.

Kononoff, P. J., A. J. Heinrichs, and D. R. Buckmaster. 2003. Modification of the Penn State forage and total mixed ration particle separator and the effects of moisture content on its measurements. J. Dairy Sci. 86:1858-1863.

Krawczel, P., and R. Grant. 2009. Effects of cow comfort on milk quality, productivity, and behavior. Pages 15-24 in Proc. 48th Annu. Meet. Natl. Mastit. Counc., Charlotte, NC. National Mastitis Council, Verona, WI.

Maltz, E. 1997. The body weight of the dairy cow: III. Use of online management purposes of individual cows. Livest. Prod. Sci. 48:187-200.

Maltz, E., A. Antler, I. Halachmi, and Z. Schmilovitch. 2009. Precision concentrate rationing to the dairy cow using on-line daily milk composition sensor, milk yield and body weight. Page 17 in Proc. 4th ECPLF, Wageningen, the Netherlands. Wageningen Academic Academic Publishers, Wageningen, the Netherlands.

Maltz, E., S. Devir, O. Kroll, B. Zur, S. L. Spahr, and R. D. Shanks. 1992. Comparative responses of lactating cows to total mixed ration or computerized individual concentrates feeding. J. Dairy Sci. $75: 1588-1603$.

Maltz, E., S. Devir, J. H. M. Metz, and H. Hogeveen. 1997. The body weight of the dairy cow: I. Introductory study into body weight changes in dairy cows as a management aid. Livest. Prod. Sci. 48:175-186.
Marsh, W. H., B. Fingerhut, and H. Miller. 1965. Automated and manual direct methods for the determination of blood urea. Clin. Chem. 11:624-627.

Mertens, D. R. 1997. Creating a system for meeting the fiber requirements of dairy cows. J. Dairy Sci. 80:1463-1481.

Mizrach, A., U. Flitsanov, E. Maltz, S. L. Spahr, and J. E. Novakofski. 1998. Ultrasonic assessment of body condition changes of the dairy cow during lactation. Trans. ASAE 42:805-812.

NAHMS. 2002. Part II: Changes in the United States Dairy Industry, 1991-2002. \#N388.0603 USDA:APHIS:VS,CEAH, National Animal Health Monitoring System, Fort Collins, CO.

NRC. 2001. Nutrient Requirements of Dairy Cattle. 7th rev. ed. Natl. Acad. Sci., Washington, DC.

Oba, M., and M. S. Allen. 2003. Effects of corn grain conservation method on feeding behavior and productivity of lactating dairy cows at two dietary starch concentrations. J. Dairy Sci. 86:174183.

Schneider, B. H., and W. P. Flatt. 1975. The indicator method. Page 168 in the Evaluation of Feeds Through Digestibility Experiments. University of Georgia Press, Athens, GA.

Spahr, S. L., R. D. Shanks, G. C. McCoy, E. Maltz, and O. Kroll. 1993. Lactation potential as a criterion for total mixed ration feeding strategy for dairy cows. J. Dairy Sci. 76:2723-2735.

Valadares, R. F. D., G. A. Broderick, S. C. Valadares Filho, and M. K. Clayton. 1999. Effect of replacing alfalfa silage with high moisture corn on ruminal protein synthesis estimated from excretion of total purine derivatives. J. Dairy Sci. 82:2686-2696.

Van Soest, P. J., J. B. Robertson, and B. A. Lewis. 1991. Methods for dietary fiber, neutral detergent fiber and nonstarch polysaccharides in relation to animal nutrition. J. Dairy Sci. 74:3583-3597.

Weiss, W. P. 1998. Estimating the available energy content of feeds for dairy cattle. J. Dairy Sci. 81:830-839.

Williams, C. H., D. J. David, and O. Iismaa. 1962. The determination of chromic oxide in faeces samples by atomic absorption spectrophotometry. J. Agric. Sci. 59:381-385. 